\title{
What controls salt-detached contraction in the translational domain of the outer Kwanza Basin, offshore Angola? \\ DOI:
}

10.1111/bre.12539

\section{Document Version}

Final published version

Link to publication record in Manchester Research Explorer

Citation for published version (APA):

Erdi, A., \& Jackson, C. A. L. (2021). What controls salt-detached contraction in the translational domain of the outer Kwanza Basin, offshore Angola? Basin Research, 33(3), 1880-1905. https://doi.org/10.1111/bre.12539

\section{Published in:}

Basin Research

\section{Citing this paper}

Please note that where the full-text provided on Manchester Research Explorer is the Author Accepted Manuscript or Proof version this may differ from the final Published version. If citing, it is advised that you check and use the publisher's definitive version.

\section{General rights}

Copyright and moral rights for the publications made accessible in the Research Explorer are retained by the authors and/or other copyright owners and it is a condition of accessing publications that users recognise and abide by the legal requirements associated with these rights.

\section{Takedown policy}

If you believe that this document breaches copyright please refer to the University of Manchester's Takedown Procedures [http://man.ac.uk/04Y6Bo] or contact uml.scholarlycommunications@manchester.ac.uk providing relevant details, so we can investigate your claim.

\section{OPEN ACCESS}




Basin
Research

\title{
What controls salt-detached contraction in the translational domain of the outer Kwanza Basin, offshore Angola?
}

\author{
Aurio Erdi $^{1,2}$ | Christopher A.-L. Jackson ${ }^{1}$
}

${ }^{1}$ Basin Research Group (BRG), Department of Earth Science and Engineering, Imperial College, London, UK

${ }^{2}$ Research Center for Geotechnology, Indonesian Institute of Science, Bandung, Indonesia

\section{Correspondence}

Aurio Erdi, Basin Research Group (BRG), Department of Earth Science and Engineering, Imperial College, Prince Consort Road, London, SW7 2BP, UK. Email: a.erdi18@imperial.ac.uk

\section{Funding information}

Lembaga Pengelola Dana Pendidikan

\begin{abstract}
It is now well-established that base-salt relief drives complex deformation patterns in the mid-slope domain of salt-bearing passive margins, in a location classically thought to be dominated by simple horizontal translation. However, due to a lack of detailed studies drawing on high-quality, 3D seismic reflection data, our understanding of how base-salt relief controls four-dimensional patterns of salt-related deformation in natural systems remains poor. We here use 3D seismic reflection data from, and structural restorations of the Outer Kwanza Basin, offshore Angola to examine the controls on the evolution of variably oriented salt anticlines, rollers, and walls, and related normal and reverse faults. We show that the complex geometries and kinematics of predominantly contractional salt structures reflect up to $22 \mathrm{~km}$ of seaward flow of salt and its overburden across prominent base-salt relief. More specifically, this contractional deformation occurs where the seaward flow of salt is inhibited due to: (a) it flowing being forced to flow up, landward-dipping ramps; (b) it encountering thicker, slower-moving salt near the base of seawarddipping ramps; or (c) the formation of primary salt welds at the upper hinge of seaward-dipping ramps. The rate at which salt and its overburden translates seaward varies along strike due to corresponding variations in the magnitude of base-salt relief and, at a larger, more regional scale, primary salt thickness. As a result of these along-strike changes in translation rate, overburden rotation accompanies bulk contraction. Our study improves our understanding of salt-related deformation on passive margins, highlighting the key role of base-salt relief, and showing contraction, extension and rotation are fundamental processes controlling the structural style of the mid-slope translational domains of salt basins.
\end{abstract}

\section{K E Y W O R D S}

base-salt relief, passive margin, salt tectonics, salt weld, section restoration, shortening, structural geology

This is an open access article under the terms of the Creative Commons Attribution License, which permits use, distribution and reproduction in any medium, provided the original 


\section{1 | INTRODUCTION}

Salt-bearing passive margins are typically characterized by thin-skinned, gravity-driven deformation above a salt layer. Kinematically-linked domains of the deformation form (e.g. Brun \& Fort, 2004, 2011; Rowan et al., 2004), with the upslope domain represented by extensional structures such as salt-detached faults and associated salt rollers and rafts (e.g. Brun \& Mauduit, 2009; Duval et al., 1992; Lundin, 1992; Rowan et al., 1999), whereas the downslope domain is represented by contractional structures such as salt anticlines and salt-detached thrusts (e.g. Cramez \& Jackson, 2000; Hudec \& Jackson, 2004). These two domains are commonly connected by an intermediary, mid-slope, translational domain (e.g. Cramez \& Jackson, 2000; Davison et al., 2012; Jackson et al., 2015; Quirk et al., 2012), which has historically been viewed as an area of relatively little deformation, characterized primarily by horizontal translation. However, relatively recent studies using $2 \mathrm{D}$ seismic reflection data (or 2D profiles through 3D data) and physical models have demonstrated that the mid-slope domain can be strongly deformed, and can experience multiple phases of extensional and contractional deformation, if the salt and its overburden translate seaward above base-salt relief and/or encounter salt weld (Figure 1a,c; e.g. Dooley \& Hudec, 2017; Ferrer et al., 2017; Dooley et al., 2017, 2018; Duffy et al., 2019). Ramp-syncline basins (RSBs) may also develop within this domain if base-salt relief is present (e.g. Evans \& Jackson, 2019; Jackson \& Hudec, 2005; Peel, 2014; Pichel et al., 2018). Despite offering an improved understanding of the regional kinematics of salt-bearing passive margins, regional studies using only $2 \mathrm{D}$ seismic data are limited in that they provide only a two- rather than three-dimensional view of how base-salt relief controls mid-slope salt tectonics and related overburden deformation. Furthermore, we have a poor understanding of how salt welding, a key process during salt tectonics, impacts horizontal translation and related salt-related structural style. Ultimately, studies of natural systems help to test the predictions of physical models (e.g. Brun \& Fort, 2004, 2011).

A recent study by Evans and Jackson (2019) used 3D seismic reflection data from the mid-slope domain of the Outer Kwanza Basin, offshore Angola to show how basesalt relief controlled the temporal and spatial development of ramp-syncline basins (RSBs; Figure 2a). Their threedimensional study of this natural salt-tectonic system also showed how changes in the downdip volumetric flux and velocity of the salt caused local extension or contraction of the salt and its overburden, associated with local acceleration or deceleration of the salt, respectively. This interaction with base-salt relief created locally variable strain fields that deformed the salt and its overburden, overprinting the broader, margin-scale salt tectonics typically associated

\section{Highlight}

- Deformations in the mid-slope domain of the Outer Kwanza Basin are characterized by saltdetached contractional structures and not simply pure horizontal translation.

- Contractional structures dominate due to salt flux variations across rift-related base-salt relief and salt welding.

- Translation and contraction are accompanied by bulk rotation and strike-slip-related deformation of the overburden.

- Salt and overburden structures in the study area translated $12.6-22 \mathrm{~km}$ seaward since the Late Albian.

with gravity gliding and spreading. Evans and Jackson (2019) also suggest that an along-strike (to the SE) increase in regional salt thickness resulted in the salt and its overburden translating seaward. As a result, ramp-syncline basins and associated salt diapirs were rotated clockwise during translation. Their study, however, did not establish how the specific base-salt structural configurations in the mid-slope domain controlled specific salt-related structural styles, nor spatial variations in the rate of seaward translation of the salt and its overburden.

Our study develops the ideas presented in and uses the kinematic framework defined by Evans and Jackson (2019) to show that the mid-slope translational domain can be strongly deformed in response to multiphase extension and contraction. As predicted by physical models, this complex deformation relates to the translation of salt and its overburden above base-salt relief. Our high-quality 3D seismic reflection dataset allows us to examine the spatial distribution of and relationship between base-salt relief, salt thickness and salt structural style, and the supra-salt structural framework. By restoring several subregional seismic profiles, we identify the impact these relationships have on the location and rate of seaward translation of salt and its overburden. Furthermore, we demonstrate that base-salt relief and the formation of primary salt welds are key controls on the geometry, distribution and kinematics of contractional structures in the mid-slope domain of salt basins (Figure 1a,c).

\section{2 | GEOLOGICAL SETTING}

The Outer Kwanza Basin is an offshore sub-basin of the Kwanza Basin, Angola (Figure 2; Brownfield \& Charpentier, 2006; Jackson \& Hudec, 2009; Lundin, 1992). 
(a) Early stage:

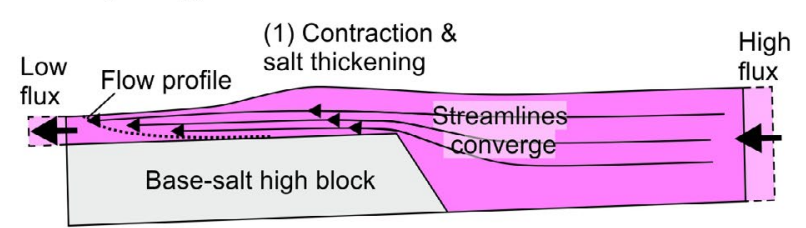

(b) Early stage: Inflation

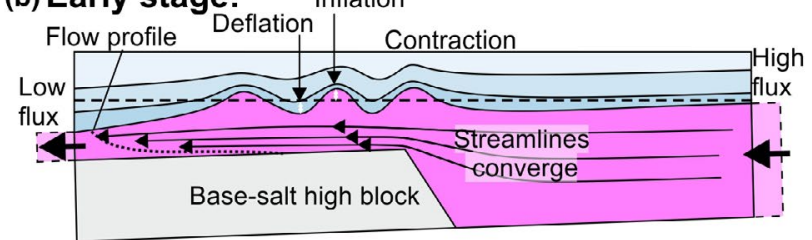

(1) Salt velocity increment causes extension
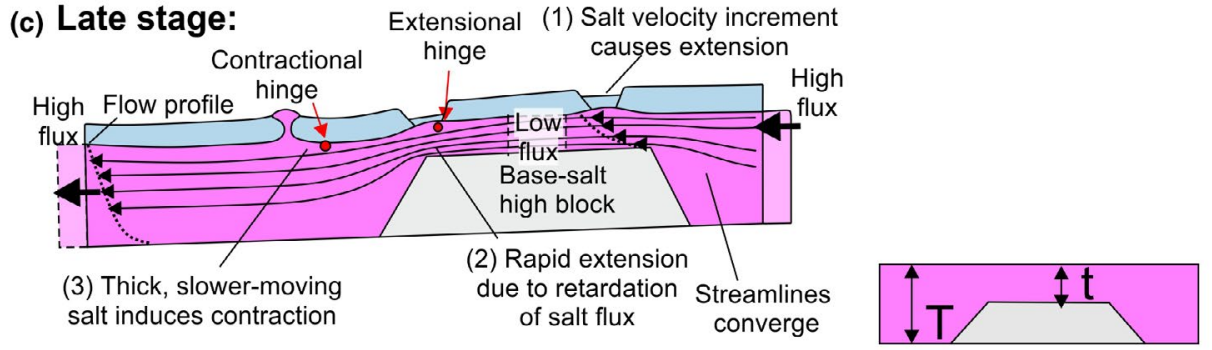

F I G URE 1 Schematic diagram illustrating the types of salt and overburden structures that form in response to the flow of salt across base-salt relief. Salt is thin (t) across the base-salt high block and thick (T) adjacent to this. (a) During the early stages of flow onto a landward-dipping ramp, convergent intrasalt streamlines drive an increase in salt flux, and an acceleration in salt and its overburden. Contraction and salt thickening occur, allowing salt velocity to increase through time as basal drag is minimized (see below). (b) In the presence of an overburden, salt anticlines, capped by salt-cored buckle folds, can form at the top of a landward-dipping ramp. Polyharmonic buckle folds, which decrease in wavelength upwards, may form due to syn-translation thickening of overburden. Similar geometries are observed and kinematics are inferred from our study area (Figure 5b,c). (c) During the latter stages of salt flow across a landward-dipping base-salt ramp, extensional structures form (and may dissect earlier-formed contractional structures) across the crest of the high block due to an increase in salt velocity generated by an earlier phase of salt contraction and thickening. Further downdip, at the top of a seaward-dipping ramp, another flux mismatch occurs where thinner, slowermoving salt meets thicker, faster-moving salt; this generates a so-called 'extensional hinge'. Further downdip, at the base of this ramp another salt flux mismatch occurs, with faster moving salt on the ramp meeting thicker, slowing moving salt in the adjacent low; this generates a so-called 'contractional hinge'. Note the types of salt and overburden structures arising due to the interaction between flowing salt and base-salt relief (figures redrawn from Dooley et al., 2017, 2018; Jackson \& Hudec, 2017)

The basin is separated from the Inner Kwanza Basin by a basement high called the Flamingo Platform, and it is bound at its western end by the Angola Abyssal Plain and at its southern end by several volcanic seamounts. To the north, the Outer Kwanza Basin passes into the Lower Congo Basin (Brownfield \& Charpentier, 2006; Hudec \& Jackson, 2002, 2004; Jackson \& Hudec, 2005).

The Kwanza Basin initially formed during the Early Cretaceous rifting associated with the opening of the South Atlantic Ocean (Figure 3). Rifting is recorded by the development of N-to-NW-trending ridges, aNE-trending transform margin, and the formation of numerous horst-and-graben systems in the present offshore area (Brownfield \& Charpentier, 2006; Guiraud et al., 2010; Hudec \& Jackson, 2002, 2004; Karner \& Driscoll, 1999; Serié et al., 2017). During the latter stages of rifting, in response to the onset of more restricted marine conditions, a thick (up to $1.4 \mathrm{~km}$ ), Aptian salt-dominated unit was deposited, draping residual rift-related basement highs and regional thickening westward (i.e. seawards) and southward (i.e. along-strike; Evans \& Jackson, 2019; Marton et al., 2000; von Nicolai, 2011). The salt is presently relatively thick in the Outer Kwanza Basin, gradually thinning eastward onto the Flamingo Platform, where it is locally absent (Hudec \& Jackson, 2002, 2004; Jackson \& Hudec, 2005; Karner et al., 2003).
Aptian salt controlled post-rift, gravity-driven deformation and the overall tectono-stratigraphic evolution of post-Aptian sequences in the Outer Kwanza Basin (Duval et al., 1992; Lundin, 1992; Marton et al., 2000; Quirk et al., 2012). This gravity-driven salt-tectonic system comprises kinematicallylinked zones of updip extension above the Flamingo Platform and downdip contraction towards the seaward edge of the salt (Figure 2; Hudec \& Jackson, 2002, 2004). The intervening zone of bulk translation is defined by a range of structural styles that appear to define three main phases of deformation (Figure 3; Evans \& Jackson, 2019). First, during the Albian, local contractional and extensional deformation occurred due to seaward salt flow across a series of base-salt ramps, resulting in the formation of salt anticlines and rollers. Second, during the Cenomanian to Oligocene, regional seaward tilting of the margin occurred, driven by post-rift thermal subsidence focused along the western edge of the Outer Kwanza Basin. This initiated regional seaward gliding, translation and rotation of the overburden above base-salt relief. During this phase, salt flow across base-salt highs generated overburden extension and the formation of rafts, and locally, where contraction occurred, salt anticlines. Third, during the Oligocene and Miocene, salt-detached seaward translation and rotation of the overburden continued. Local extension 


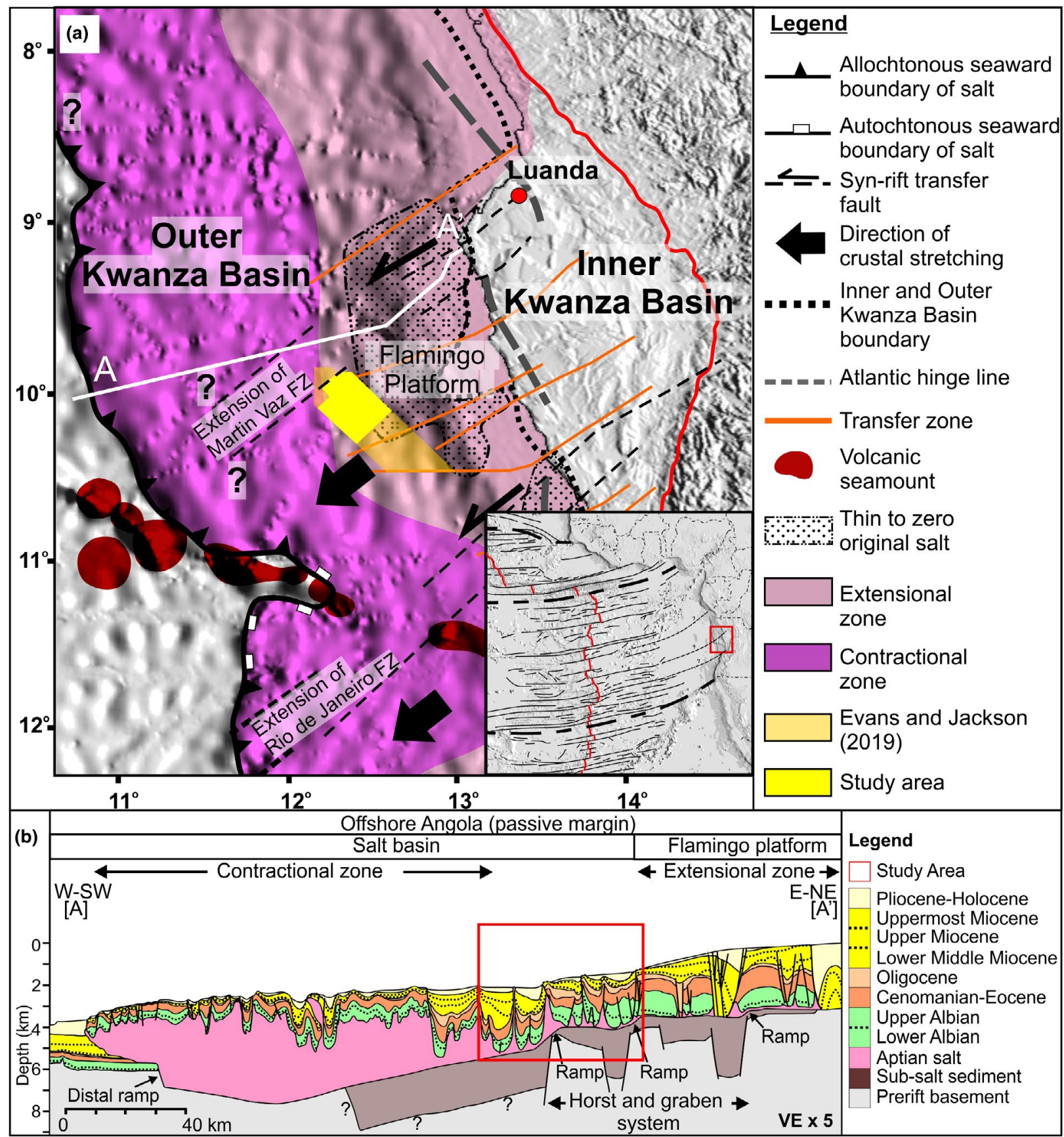

F I G U RE 2 (a) Simplified regional structural map illustrating the key tectonic features and domains offshore Angola, (b) Regional geoseismic section across the Outer Kwanza Basin, offshore Angola. The approximate location of the study area is indicated by the red box. Note the presence of prominent base-salt relief, related to the underlying (i.e. sub-salt), rift-related, horst-and-graben system (modified from GEBCO Compilation Group, 2020; Guiraud et al., 2010; Hudec \& Jackson, 2002, 2004; Jackson \& Hudec, 2005; Marton et al., 2000; Moulin et al., 2005; Serié et al., 2017)

drove reactive diapirism and the rise of salt walls, in some cases by the breaching of the roofs of previously formed salt anticlines. Elsewhere, in contractional strain fields, some preexisting structures were locally shortened. Finally, uplift of the African continent during the Miocene to Recent continued to drive seaward translation of salt and rotation of the overburden, but at an accelerated rate. Translation, and local shortening and rotation caused squeezing and active rise of some salt walls. Salt welding, and an increase in sediment accumulation rate relative to diapir rise rate, eventually led to the burial of salt structures and a decrease in margin-scale salt tectonics.

We focus on an area located between the seawardedge of the Flamingo Platform, just south of the Martin 
F IG URE 3 Simplified regional tectonostratigraphic framework of the Outer Kwanza Basin, offshore Angola. Note the protracted, multiphase salt-tectonics that are associated with significant seaward (i.e. to the SW) flow and rotation of salt and its overburden (adapted from Evans \& Jackson, 2019; Hudec \& Jackson, 2004)

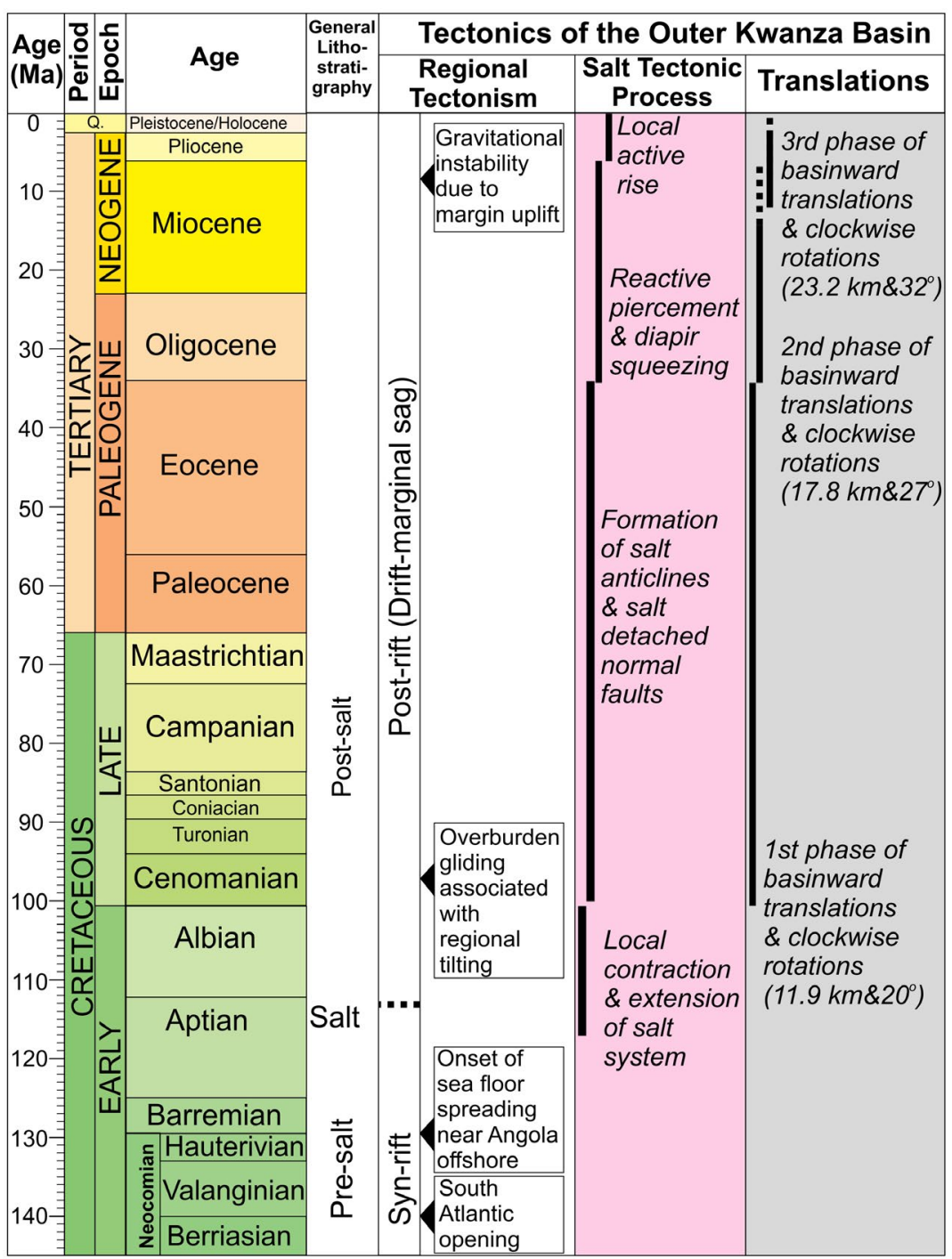

Vaz Transform Fault and above several rift-related horsts (Figure 2; i.e. in the 'diapir' and 'monocline' domains of Hudec \& Jackson, 2004; see also Guiraud et al., 2010). The diapir domain contains a range of salt structures formed in response to extension and contraction (i.e. salt anticlines, rollers, walls and sheets; Evans \& Jackson, 2019; Hudec \& Jackson, 2004). The monocline domain contains RSBs formed due to the seaward translation of salt and its overburden (e.g. Dooley et al., 2017, 2018; Evans \& Jackson, 2019; Jackson \& Hudec, 2005; Pichel et al., 2018, 2019). By analysing these RSBs and flanking salt structures, Evans and Jackson (2019) showed that overburden in this area underwent total of ca. $23 \mathrm{~km}$ of seaward translation and a clockwise plan-view rotation of ca. $32^{\circ}$. However, we here demonstrate that magnitude of the seaward translation and rotation might not represent regional-scale kinematics related to large-scale, along-strike changes in salt thickness; instead, this style of deformation may reflect the more local control of base-salt relief.

\section{3 | DATASET AND METHODS}

\subsection{Datasets and seismic interpretation}

This study uses $1,276 \mathrm{~km}^{2}$ of a $2,915 \mathrm{~km}^{2}$, zero-phase processed, post-stack depth migrated (PSDM) BroadSeis ${ }^{\mathrm{TM}} 3 \mathrm{D}$ seismic dataset that covers the Outer Kwanza Basin, offshore Angola (Figure 2). Due to confidentiality reasons, the data are cropped at the base-salt (ca. $-5.5 \mathrm{~km}$ ). However, the morphology of the base-salt surface, which controls many of the salt-related structural styles documented here and by Evans and Jackson (2019), is clear. This dataset has inline (northwest-southeast) and crossline (northeast-southwest) spacing of $25 \mathrm{~m}$; inlines and crosslines are oriented broadly normal and perpendicular to the bulk south-westerly translation direction, respectively. The seismic dataset has a record length of $10 \mathrm{~km}$ and a vertical sample rate of $2 \mathrm{~m}$, with a vertical resolution of ca. $3.5 \mathrm{~m}$ and $30 \mathrm{~m}$ at the seabed and at a depth of ca. $5 \mathrm{~km}$, respectively. The data are displayed 
with the Society of Exploration Geophysicists (SEG) "normal' polarity convention; i.e. a downward increase and decrease in acoustic impedance are represented by a positive reflection (white) and a negative (black) reflection event, respectively. We mapped eight seismic horizons, the ages of which are determined by comparing our data to ageconstrained regional seismic profiles presented by other authors (see Table 1). Age constraints allow us to establish the relative timing of different salt-tectonic events by identifying key seismic-stratigraphic relationships (e.g. onlap, truncation).

\subsection{Restoration analysis}

Quantitative structural restorations were undertaken on several SW-trending cross-sections oriented broadly parallel to the regional (salt) tectonic transport direction. These restorations allowed us to: (a) validate our seismic interpretation; (b) unravel the two-dimensional evolution of salt-related local contractional structures; (c) illustrate the quasi-3D kinematics of salt-related deformation using serial 2D cross-sections; and (d) calculate spatial variations in the magnitude of seaward translation of the suprasalt (see Appendix S1 and S2 for full detail information of restoration, methodology and algorithms). A key constraint on our structural restoration were the RSBs, which are inferred to initiate at the top of fixed (i.e. static) base-salt ramps (cf. Dooley \& Hudec, 2017; Dooley et al., 2017, 2018; Hudec \& Jackson, 2004; Jackson \& Hudec, 2005; Rowan \& Ratliff, 2012).

\section{4 | BASE-SALT STRUCTURAL} STYLE

We first describe the morphology of the base-salt; this provides a spatial framework for understanding the basesalt-induced deformation identified within the salt and its overburden (Figure 4a). The base-salt dips broadly to the SW. Superimposed on this are three distinctive trends (i.e. NW-, $\mathrm{N}$-, NE-trending) defined by relatively steeply dipping ramps $\left(>10^{\circ}\right)$. In the northeast, the ramps trend NW, are ca. 36-km long, and dip up to $47^{\circ}$ seaward, defining the seaward edge of the Flamingo Platform (Figures 2, 6 and 7). In the southwest and the south, the base-salt ramps trend NW-to-N and dip up to $25^{\circ}$, forming an array of concave, seaward-dipping ramps (Figures 4a, 5a-c and 6b). Between the north-eastern, and southern and south-eastern areas, we identify four structural highs that define local relief of ca. 500-1000 m. These four highs trend NW-to-N and are bound by dip of $10^{\circ}-45^{\circ}$ dipping ramps that face either landward or seaward $(\mathrm{V}, \mathrm{W}$, $\mathrm{X}, \mathrm{Y}$ and Z; Figures 4a, 5a, 6a,b and 7). Although our lack of sub-salt seismic imaging means that we cannot identify the origin of these structural highs and flanking ramps, the dips of the ramps are consistent with the dips of subsalt normal faults (ca. 50 ${ }^{\circ}$ ) identified in the Lower Congo Basin (cf. Zone 2 of Moulin et al., 2005); thus, we speculated the local highs and associated ramps are fault-bounded and may be related to the Angola-Gabon horst-block system (sensu Hudec \& Jackson, 2004). The relatively flat relief $\left(<10^{\circ}\right)$ such as in the southwest and southeast (Figures 5a, 6b, and 7b,c), however, may reflect pre-rift growth strata without significant extensional faulting (cf. Zone 3 of Moulin et al., 2005). In the north

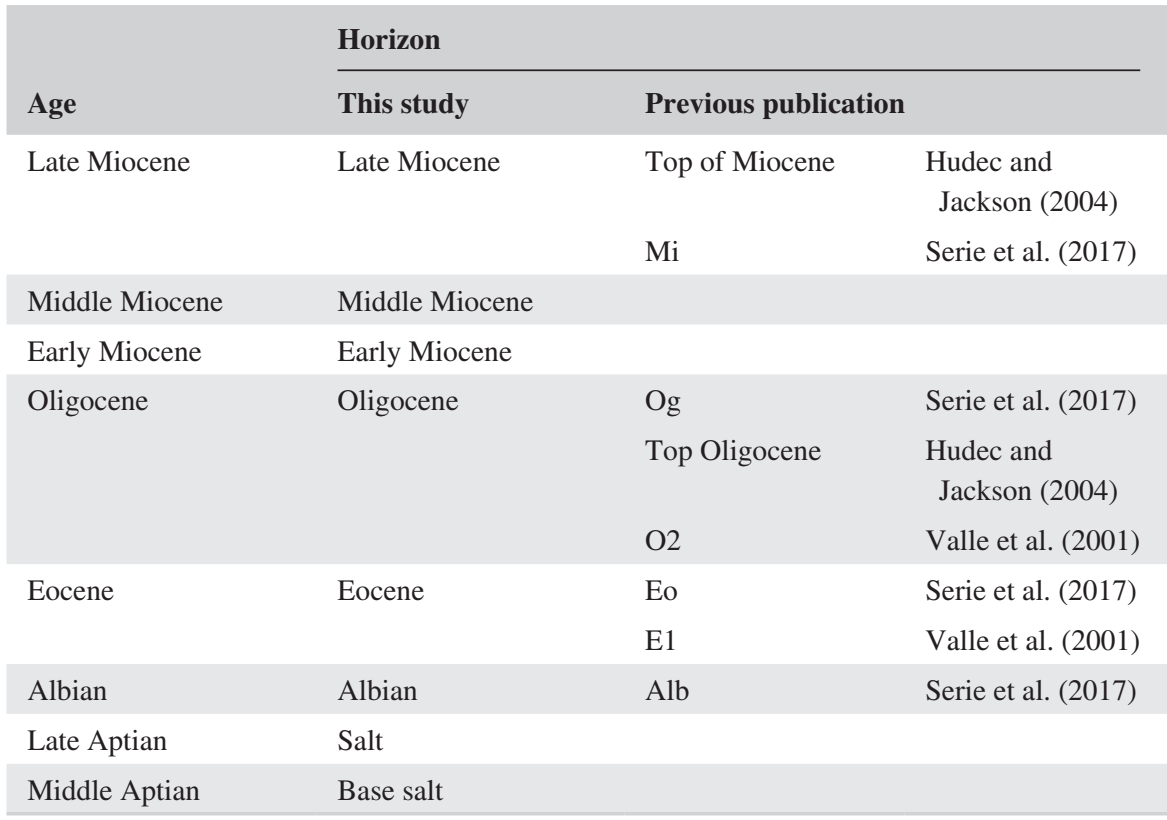

TABLE 1 Compilation of previously published ages for key seismic reflections identified in the Outer Kwanza Basin and comparison to seismic-stratigraphic framework defined in this study 

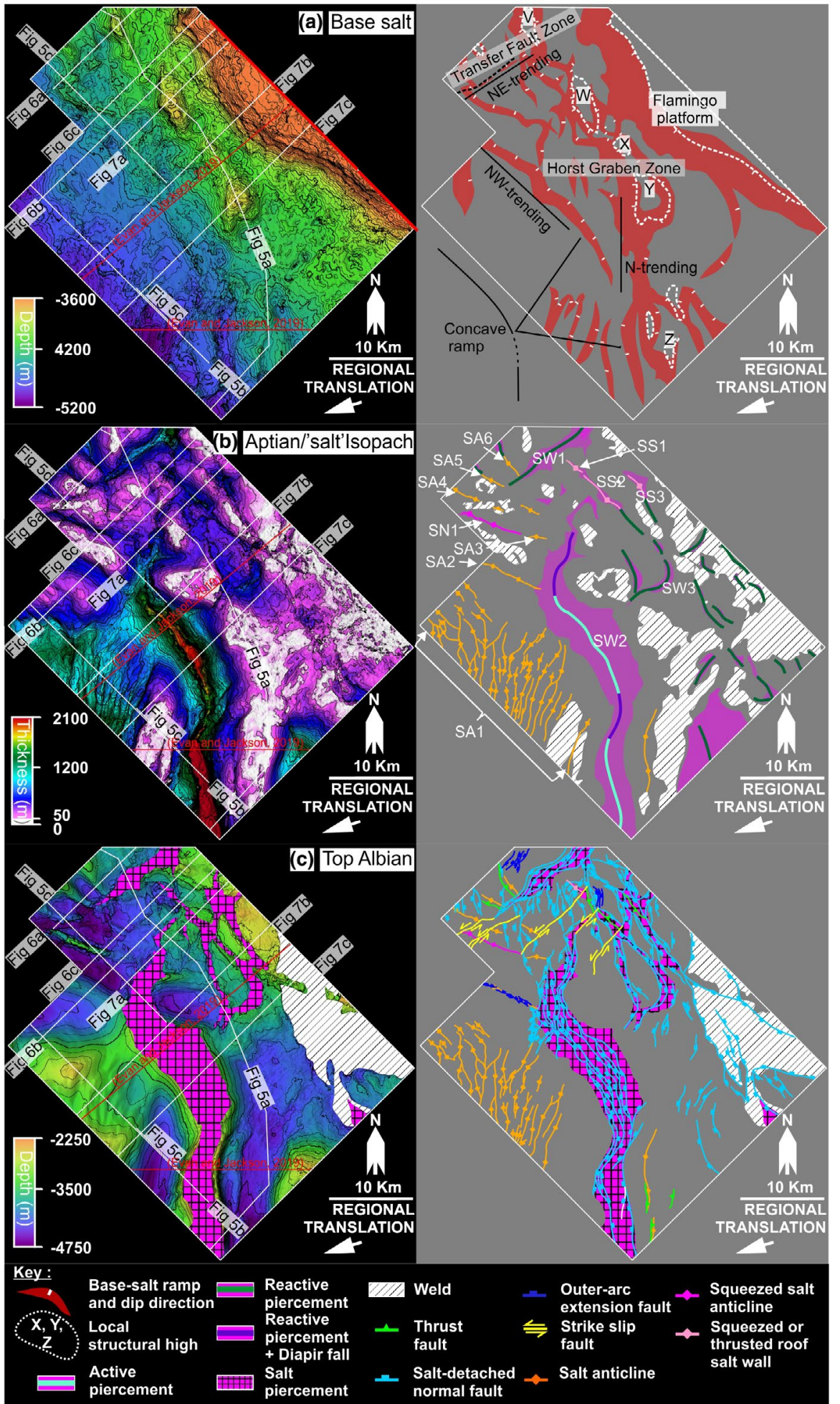

\section{Weld}

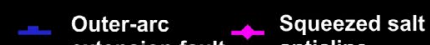
extension fault anticline

Thrust $\leftrightharpoons$ Strike slip $\_$Squeezed or fault fault thrusted roof
salt wall

F I G URE 4 (a) Depth-structure map (left) and interpretative sketch map (right) of the base-salt seismic horizon. These maps illustrate significant base-salt relief associated with complex, landward- and seaward-dipping ramps (highlighted in red), the most north-eastern of which are associated with the Flamingo Platform. (b) Isochron map (left) and interpretative sketch map (right) of the Aptian salt layer, illustrating the morphology and distribution of salt structures and flanking (primary) welds (see Table 2 for detailed description of salt structure geometry and origin). (c) Depth-structure map (left) and interpretative sketch map (right) of the top Albian seismic horizon. These maps illustrate the types and distributions of supra-salt (i.e. overburden) faults and folds (see Table 3 for description of each type of supra-salt faults) 

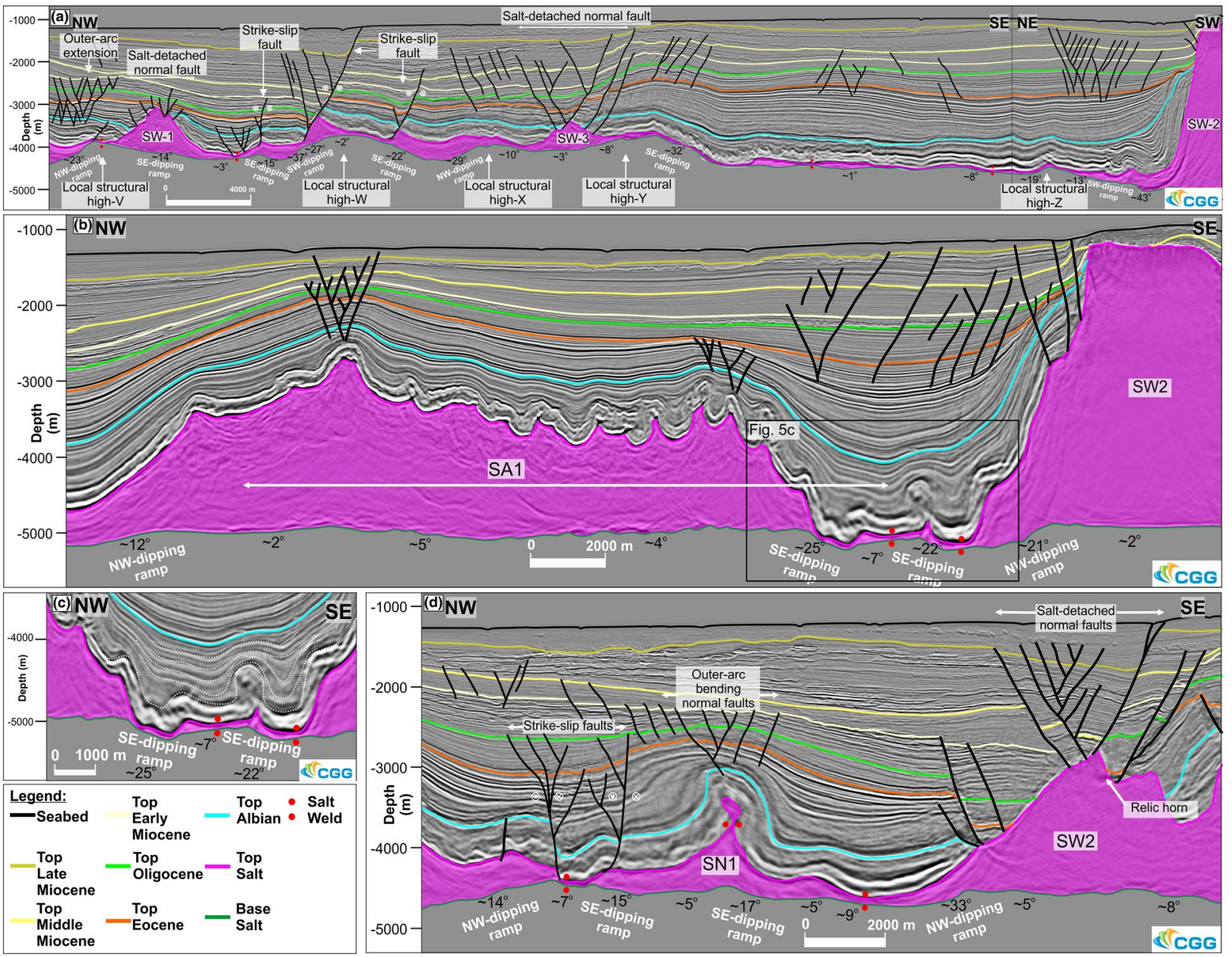

F I G U R E 5 Margin-parallel (i.e. normal to regional base-salt dip and bulk translation direction) seismic profiles illustrating salt-related structural styles (section location shown in Figure 4). (a) NW-SE-to-NE-SW-trending cross-section showing the salt and overburden structures and their present spatial relationships to base-salt highs and lows. This seismic profile illustrates salt walls, salt-detached strike-slip faults, and outer-arc extension faults above turtle anticlines. (b) NW-SE-trending cross-section showing polyharmonic salt anticlines (SA1), broadly located above areas where the base-salt is relatively flat. (c) Zoom in of (b), highlighting the detailed geometry of and overburden seismic-stratigraphic architecture associated with polyharmonic salt anticlines located just downdip of a SE-dipping base-salt ramp. Note the presence of intra-Albian growth strata. (d) NW-SE-trending cross-section illustrating salt-detached strike-slip fault adjacent to a SE-dipping base-salt ramp, outer-arc bendingrelated normal faults above a squeezed salt anticline, and a relic horn at the crest of the (extensionally) collapsed salt wall. For more details on the geometry and origin of salt and overburden structures, see Tables 2 and 3, respectively. Seismic data courtesy of CGG Multi-Client

and the southeast, we observe relatively short ( $<11 \mathrm{~km}$ long), NE-trending ramps that face either SE or NW, and which locally intersect a NW-trending ramp (Figure 4a). These NEtrending ramps are consistent with the trend of the Martin Vaz Transfer Fault (Figure 2a; sensu Moulin et al., 2005; Guiraud et al., 2010); we thus infer that these ramps are the upper crustal expression of this lithosphere-scale structure.

\section{5 | DISTRIBUTION AND STYLE OF SALT AND SUPRA-SALT STRUCTURES}

The geometry of salt and supra-salt structures varies across the study area. A salt-thickness map allows us to define the distribution of salt structures that are related purely to contraction (e.g. salt anticlines), and other structures of more variable origin (e.g. salt walls; Table 2; Figures $4 \mathrm{~b}$ and 5-7). Some salt structures are separated by primary welds, either apparent or incomplete (sensu Wagner \& Jackson, 2011), across which supra-salt strata appear to directly overlie sub-salt strata (Figure 7). A structure map of the Albian seismic horizon, which records the cumulative translation of the overburden, defines the present spatial relationships between salt and spatially related supra-salt structures (e.g. salt-detached normal faults, outer-arc bending-related normal faults, and thrusts and strike-slip faults; Table 3; Figures $4 \mathrm{c}$ and 5-7). As indicated by Evans and Jackson (2019), it is critical to note that: (a) the salt and supra-salt structures are unlikely to be in the same position 


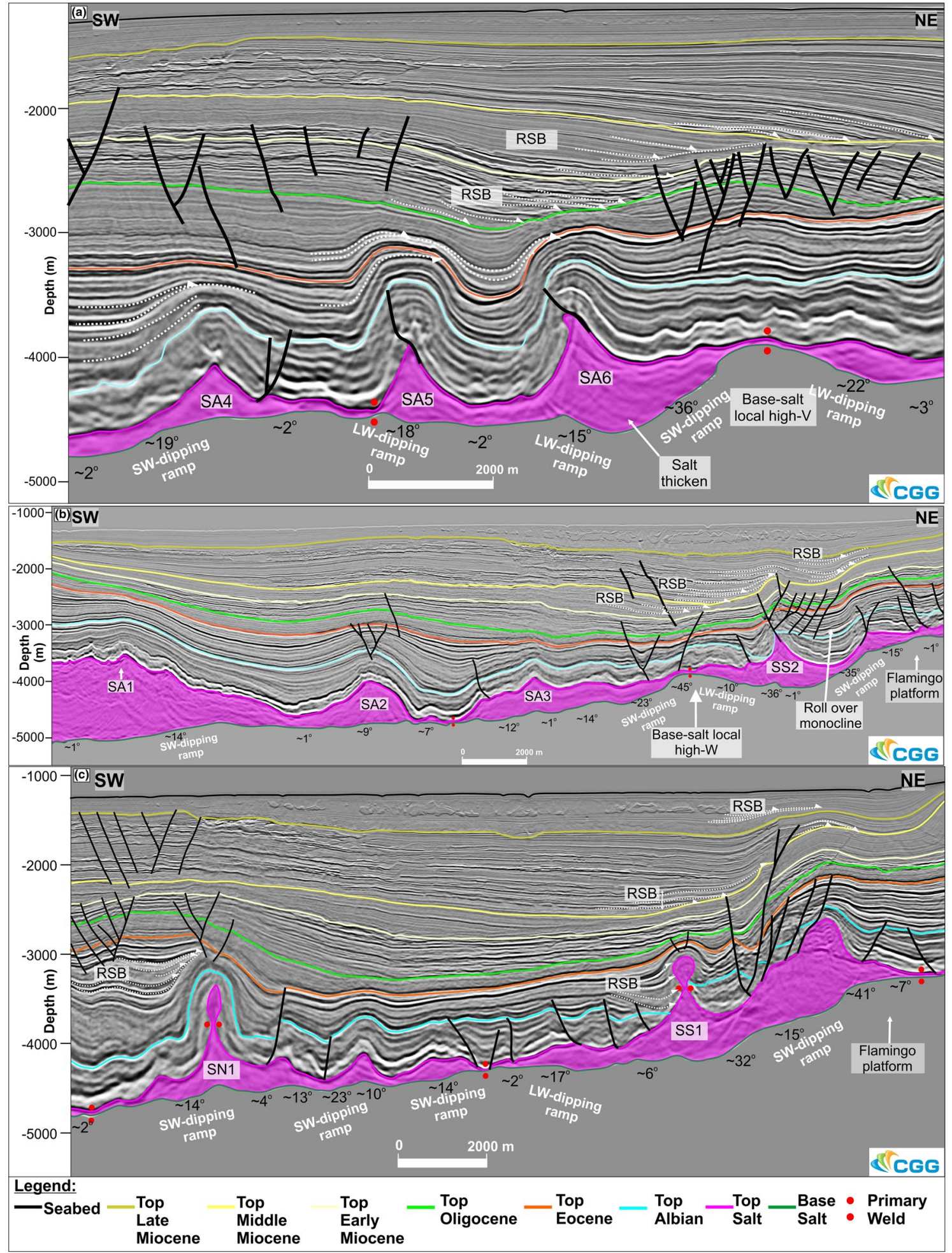

F I G URE 6 Margin-perpendicular (i.e. parallel to regional base-salt dip and bulk translation direction) seismic profiles illustrating the styles of salt-related contractional structures observed in the northern part of the study area (section location shown in Figure 4). (a) NE-SW-trending cross-section showing salt anticlines (SA4-6) that may (i.e. central and right-hand anticlines) be capped by salt-detached normal and thrust faults. These anticlines are developed at the base (i.e. south-westwards) of a major seaward-dipping ramp. (b) NE-SW-trending cross-section illustrating salt anticlines (SA1-3) and complex salt walls; the latter is overlain by a basinward-dipping monocline and several ramp syncline basins (RSBs). (c) NE-SW-trending cross-section illustrating outer-arc bending-related normal faults capping a squeezed salt anticline (SN1). Further to the northeast, a squeezed salt wall (SS1) is located at the base of the seaward-dipping ramp and is itself capped by several RSBs. The RSBs record seaward translation of salt and its overburden (see text). Seismic data courtesy of CGG Multi-Client 


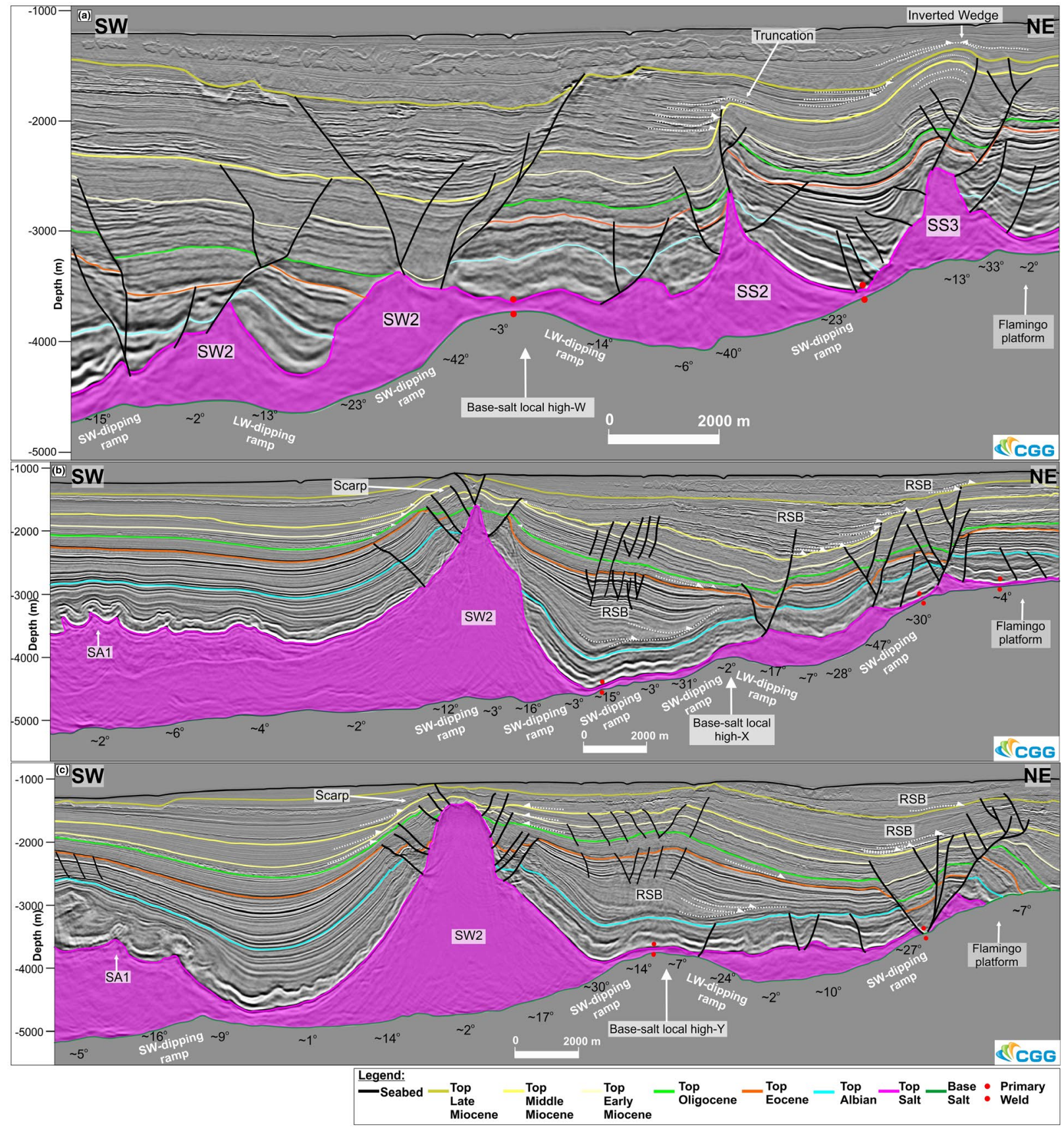

F I G U RE 7 Margin-perpendicular (i.e. parallel to regional base-salt dip and bulk translation direction) seismic profiles illustrating the styles of salt-related contractional structures observed in the central and southern part of the study area (section location shown in Figure 4). (a) NESW cross-section showing diapir fall above complex salt wall (SW2) in the centre, while the complex salt walls (SS2-3) with associated NE and SW-dipping thrust faults developed above downdip of the NW-trending, SW-dipping ramp. (b) NE-SW cross-section showing polyharmonic, salt anticline (SA1) in the south west, while in the centre the complex salt wall (SW2) are presented. Further northeast, RSBs are developed above downdip, seaward-dipping of Flamingo platform. (c) NE-SW cross-section showing the complex salt wall (SW2) in the centre above downdip, seaward-dipping of local structural high. Seismic data courtesy of CGG Multi-Client

as where they formed, given they have translated seaward a few tens of kilometres; and because of this (b) salt and suprasalt structures likely do not directly overlie the base-salt features that triggered their initial development. Finally, the salt and related supra-salt faults are overlaid by and occur within RSBs that formed purely in response to Eocene-to-Pliocene, salt-detached translation of the overburden (Figures 6 and 7b,c). However, as shown by Pichel et al. (2018), RSBs can be internally deformed by post-formation diapirism and saltrelated faulting (above SN1; Figure 6c).

Interpretative sketch maps of the main salt structures (as defined at the top salt structural level), the supra-salt structures (as defined at the Albian structural level), and a simplified base-salt structure map, show the present spatial relationship 


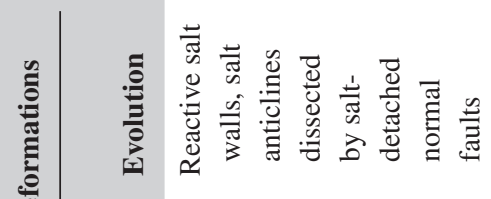

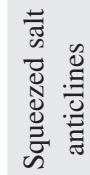

兽

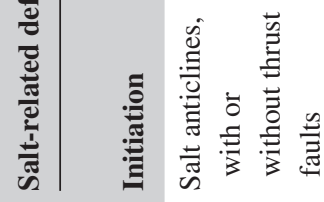

|

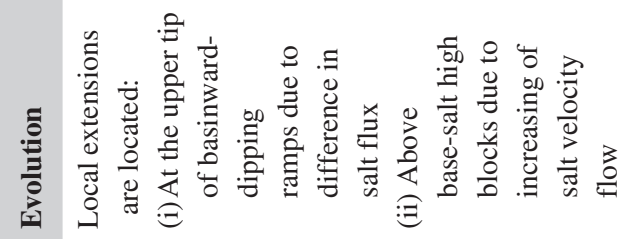

竞

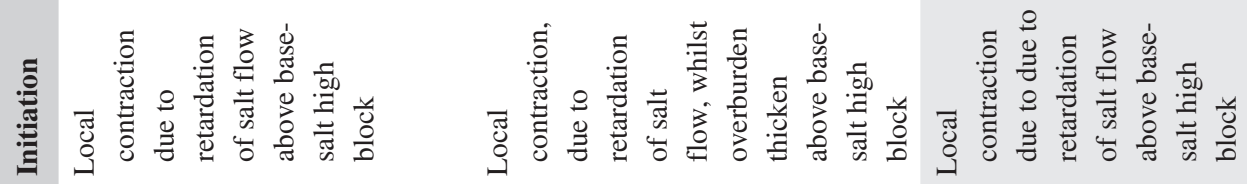

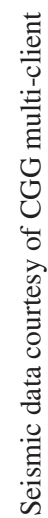

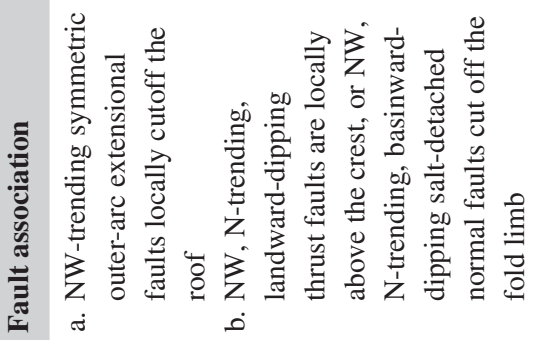

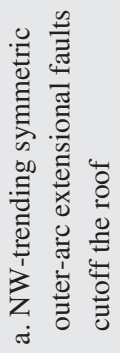

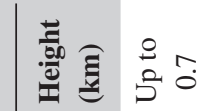

$\stackrel{2}{5}=$

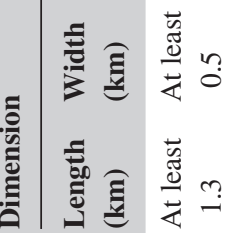

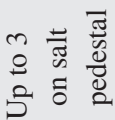

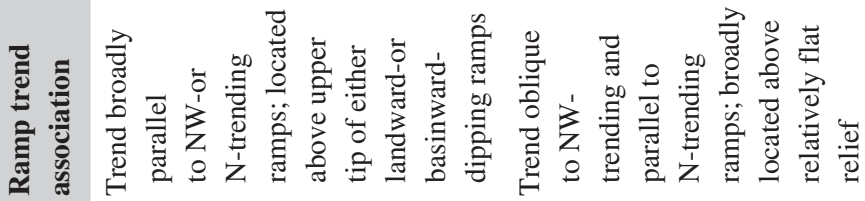

$\stackrel{0}{\infty}$

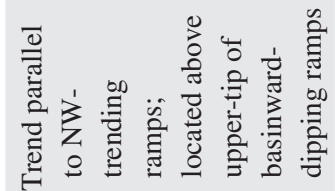
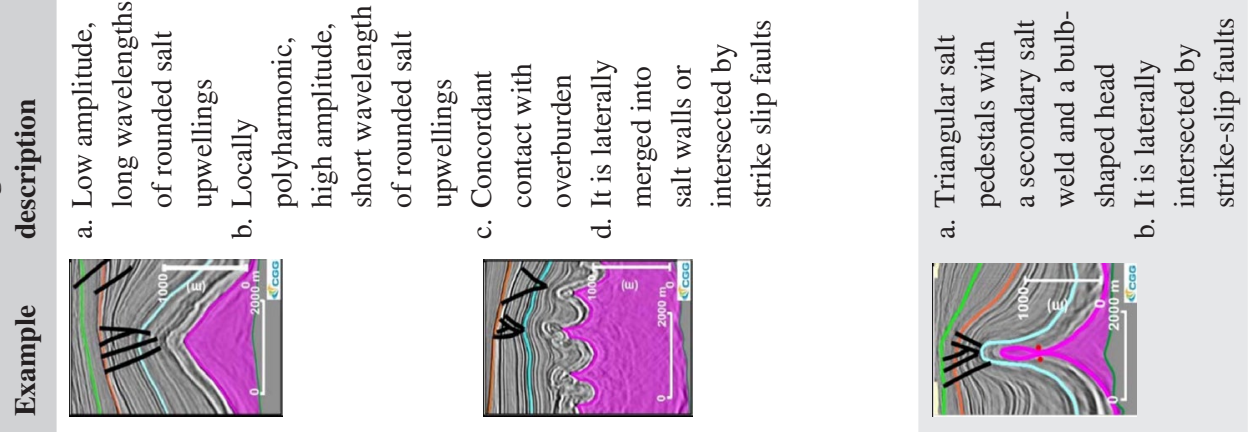

吾

岳

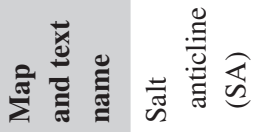

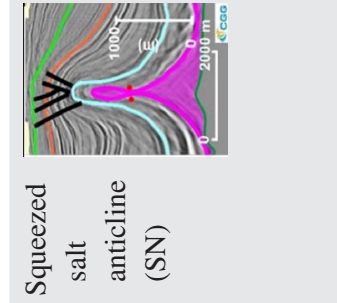




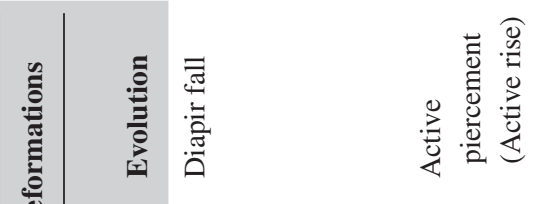

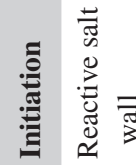

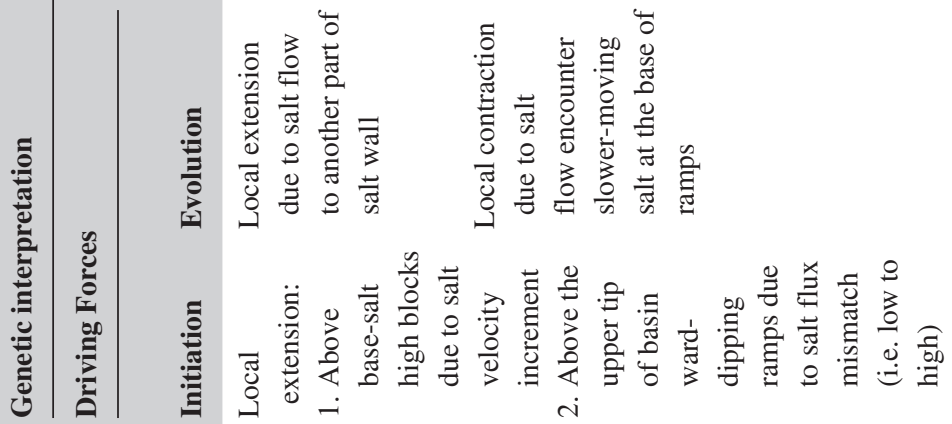

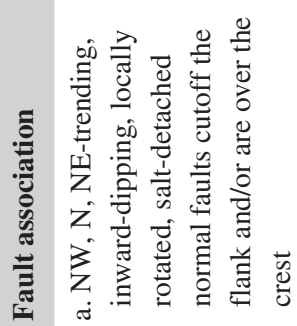

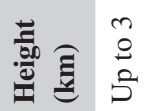

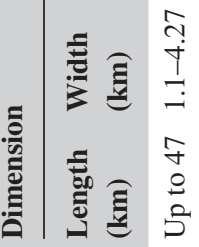

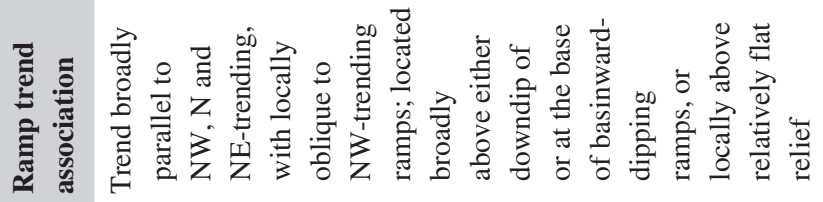
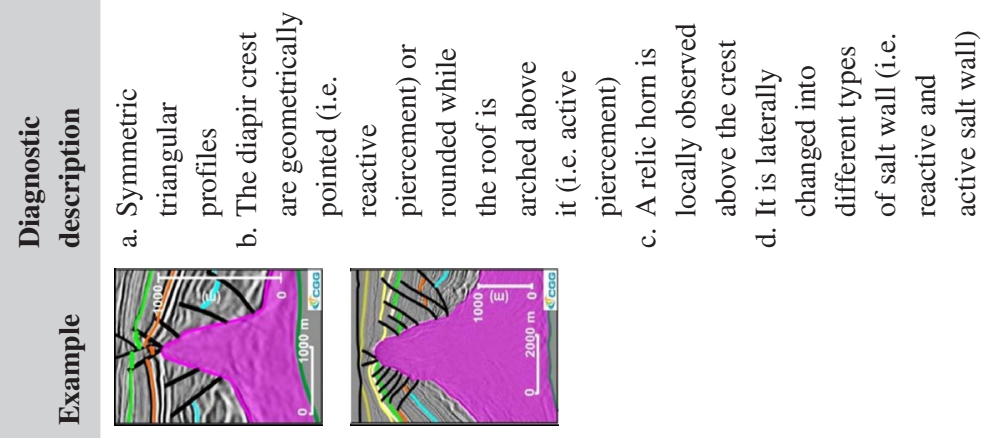

논

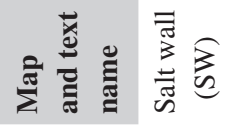



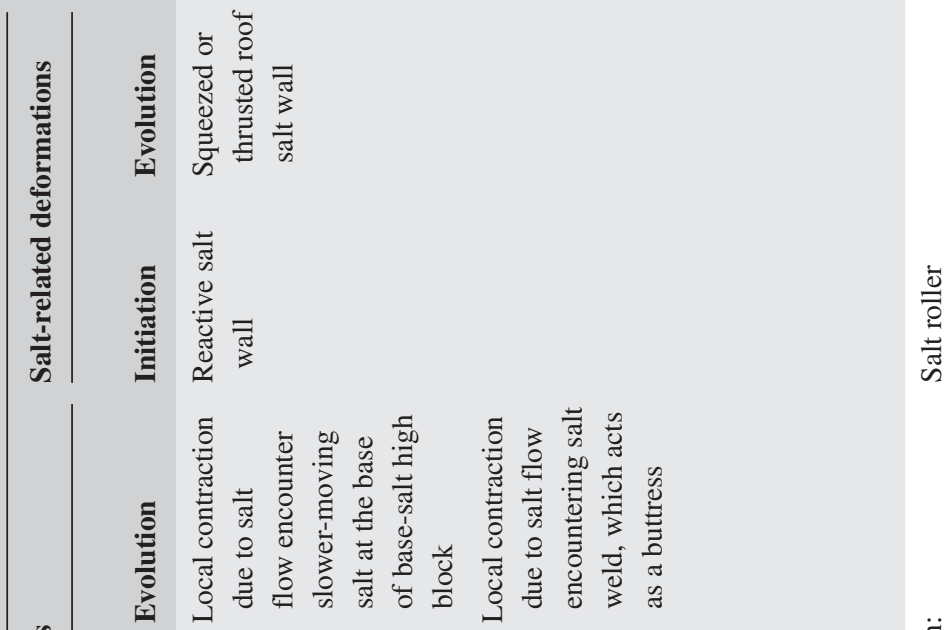

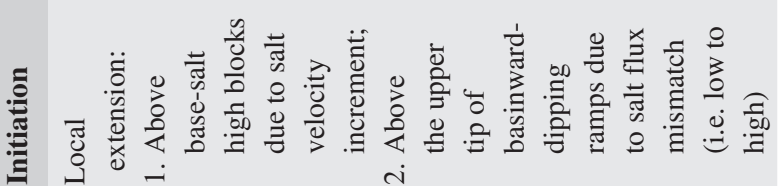
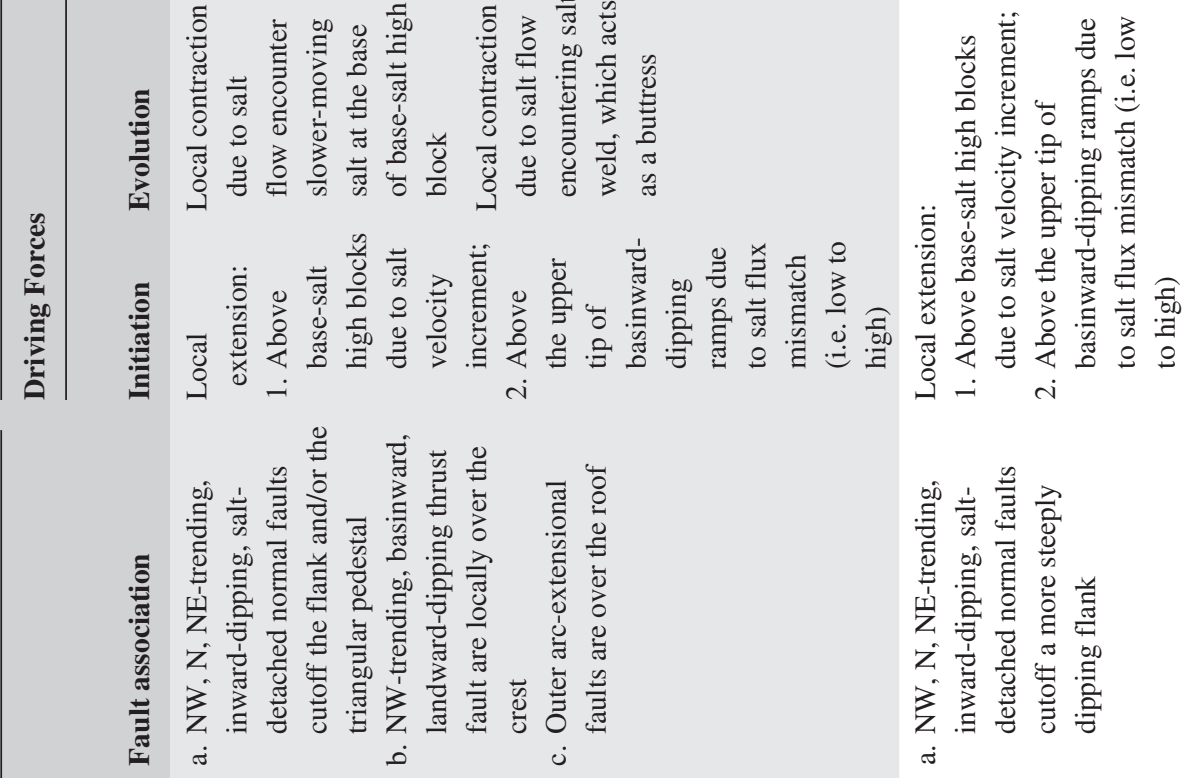

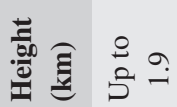

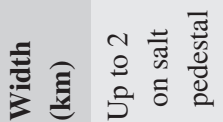

苛

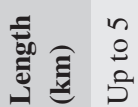

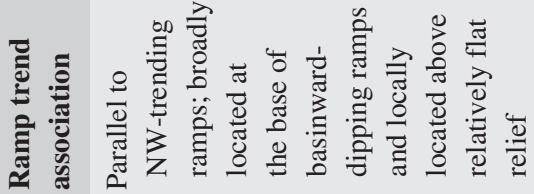
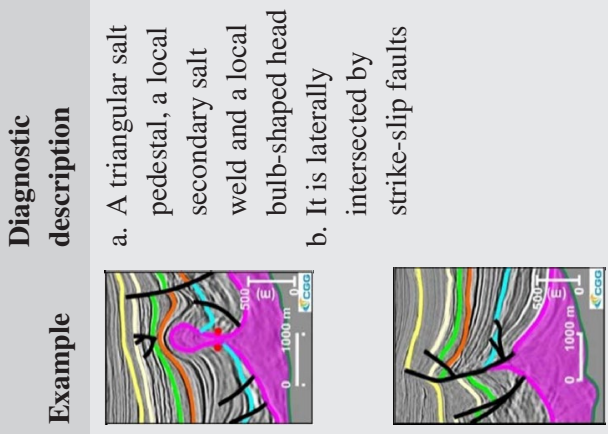

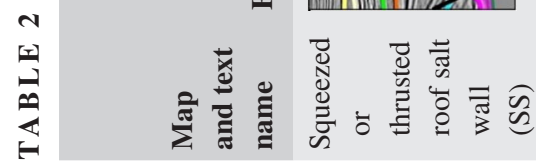

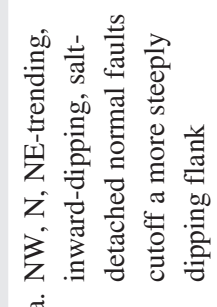

ลำ ชุ

$\dot{0}$
0
0
0
0

$\stackrel{2}{2} \stackrel{0}{\rho}$
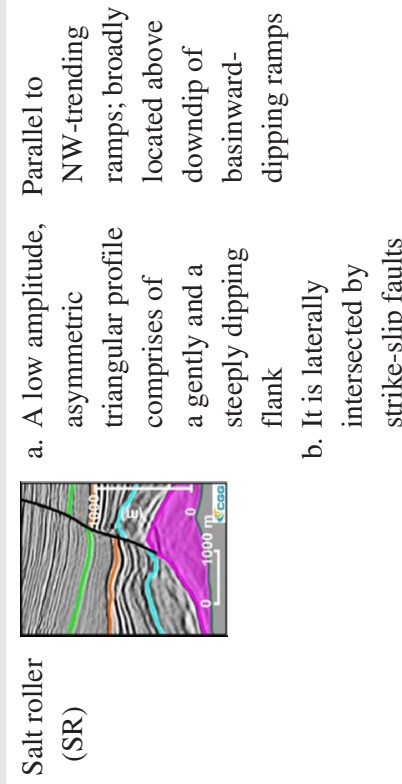


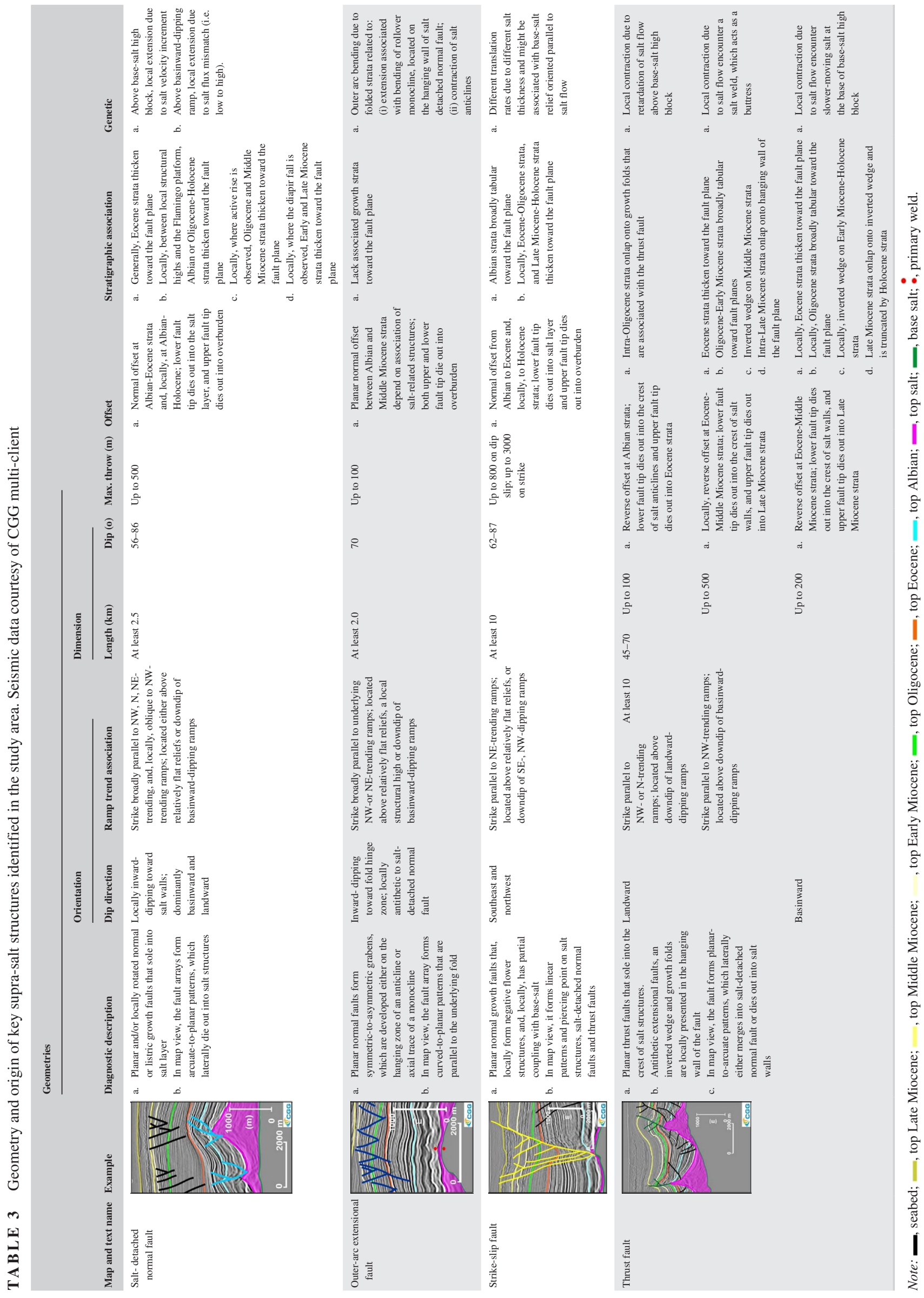


between features at all three levels (Figure 8). Both the salt and supra-salt structures vary in terms of their distribution and orientation relative to underlying base-salt features (Table 2). For example, where they are elongate (e.g. anticlines, walls), they may lie either parallel or oblique to the ramps. In other cases, these features overlie relatively flat areas at base-salt (SA1 and SW2; Figure 5b). We now describe the geometry and interpret the origin and evolution of salt and salt-related structures, with a specific focus on salt-related contractional structures. The evolution of these structures is shown by the structural restoration of selected cross-sections (Figure 9; see also Appendix S3 for a larger version of the restorations).

\section{6 | SALT-RELATED CONTRACTIONAL STRUCTURAL STYLE}

\section{1 | Salt anticlines}

\subsection{1 | Geometry}

In the southwest, salt anticlines trend broadly parallel to NE-trending, base-salt ramps, or are presently located above relatively flat areas of the base-salt surface (SA in
Table 2 and SA1; Figure 8). The anticlines above the flat areas are polyharmonic, increasing in wavelength, but decreasing in amplitude, upwards (SA1; Figures $5 \mathrm{~b}$ and $7 \mathrm{~b}, \mathrm{c}$ ). These salt anticlines are commonly overlaid by relatively thick (up to $800 \mathrm{~m}$ ) roofs, suggesting that they formed in response to contraction (Jackson \& Hudec, 2017). In the north, where the ramp changes to trend NW, the anticlines similarly change trend to stay sub-parallel to the underlying structures, being located above either seawardor landward-dipping ramps (SA3-6; Figure 8). Above seaward-dipping ramps, the limbs of these salt anticlines are commonly dissected by salt-detached normal faults, such as above the landward limb of SA4 (Figure 6a), suggesting that this anticline may have been later extended. From this point northeastward, these salt anticlines are overlain by thick roofs, underlain by still-thick salt, and have their seaward limbs offset by NW-SE-striking thrusts faults immediately above the downdip end of the underlying ramps (SA5 and SA6; Figure 6a). In a few cases in the north of the study area, highly-deformed anticlines are presently located above seaward-dipping ramps ( $\mathrm{SN}$ in Table 2 and SN1; Figure 8a). These anticlines are characterized by a triangular salt pedestal, an apparent secondary weld (sensu Wagner \& Jackson, 2011), and are sometimes overlain by normal faults inferred to accommodate

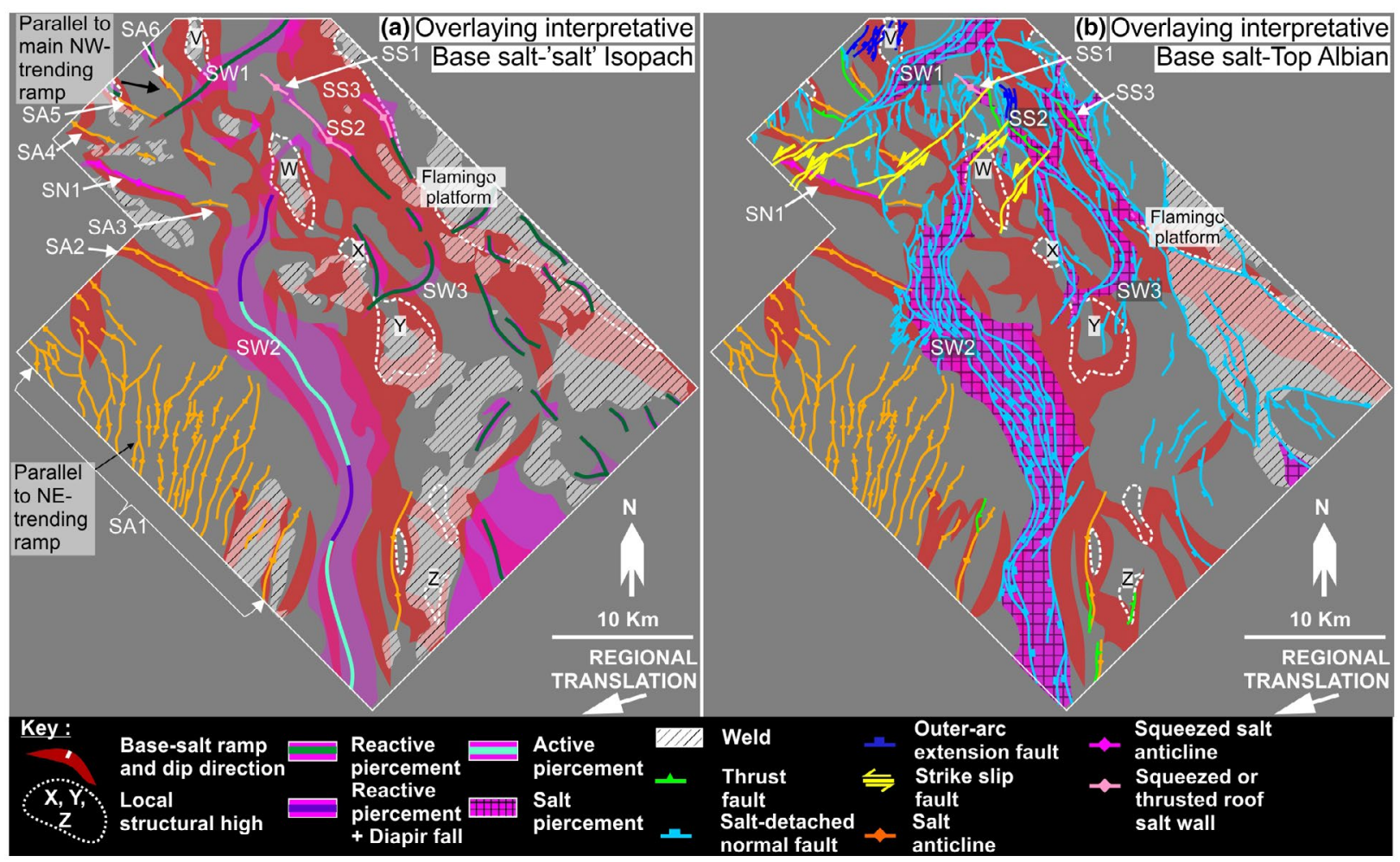

F I G URE 8 (a) A composite map illustrating the present spatial relationship between structures present at the base-of-salt (taken from Figure 4a) and overlying salt structures (taken from Figure 4b). (b) A composite map illustrating the present spatial relationship between structures at the base-of-salt (taken from Figure 4a) and overlying, supra-salt structures defined at the top Albian structural level (taken from Figure 4c) 


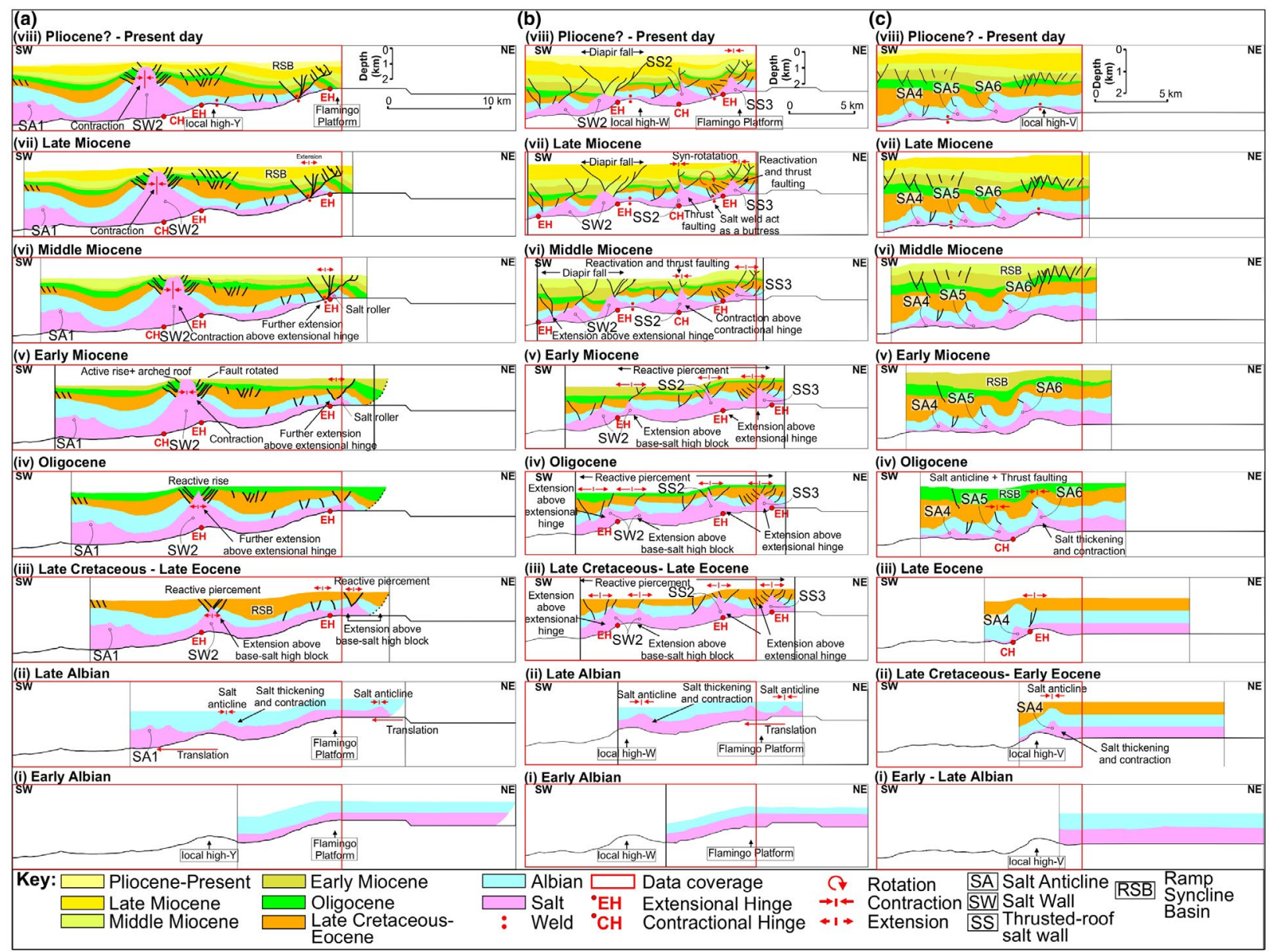

F I G URE 9 Structural restoration of margin-perpendicular (i.e. parallel to regional base-salt dip and bulk translation direction) seismic profiles (Figures 6a and 7a,c) illustrating the evolution of various salt and overburden structures in the Outer Kwanza Basin (see Appendix S3 for a larger version of the figures). (a) Restoration of a NW-SE-trending seismic profile in the south of the study area, crossing structural-high Y; (b) Restoration of a NW-SE-trending seismic profile in the centre of the study area, crossing structural-high W; (c) Restoration of a NW-SE-trending seismic profile in the north of the study area, crossing structural-high V (see Appendix S1 for detailed documentation of the key methods and assumptions)

outer-arc bending and stretching of the arched roof (SN1; Figure $6 \mathrm{c}$ ). As it is associated with a range of features, we interpret that these types of salt anticlines were amplified and laterally squeezed in response to continued horizontal shortening.

\subsubsection{Timing and structural evolution}

The salt-cored anticlines, at least those in the southwest of the study area, initiated relatively early, in the Albian, given they are flanked and overlain by intra-Albian growth strata (SA1; Figures 5b,c, 6b, and 7b,c). The salt anticlines may have formed due to: (a) buckling at the base of base-salt ramps, as relatively fast-moving thin salt encountered relatively slow-moving thicker salt (Evans \& Jackson, 2019; Jackson \& Hudec, 2005; position labelled 3; Figure 1c); and/or (b) salt thickening, and overburden deceleration and shortening upon encountering landwarddipping base-salt ramps (i.e. in cases where the anticlines are presently located on base-salt plateaus; Figure 1a; cf. Dooley et al., 2017, 2018; Pichel et al., 2019). The former interpretation is, however, not consistent with several physical models, which predict that, during the early stages of translation, a monocline rather than a salt anticline may form at the top of a seaward-dipping base-salt ramp (Dooley \& Hudec, 2017; Dooley et al., 2017, 2018; Gaullier et al., 1993). Although it is possible that such a monocline did form and was subsequently translated further seaward before growing into a salt anticline (Jackson \& Hudec, 2005), we prefer the latter interpretation, given we consistently see thickened salt immediately seaward of landward-dipping ramps (SA5 and SA6; Figure 6a).

Our structural restorations, which are based on the assumption that anticlines form due to translation across the landward-dipping side of base-salt highs, suggest salt 
anticlines in the southwest of the study area, initiated in the Late Albian (cf. Figure 1a; ii; Figure 9a,b). We propose that the polyharmonic geometry of the salt anticlines, such as observed in the southwest, reflect continuous (rather than punctuated) local contraction during overburden thickening, followed by further seaward translation (cf. Figure 1b; SA1; Figures 5b,c, 7b,c and ii; Figure 9a).

During the Eocene to Oligocene, new salt anticlines initiated and Early Cretaceous anticlines were amplified, as indicated by their flanking Eocene-to-Oligocene growth strata (SA4-6; Figure 6a). This indicates that base-salt relief-related shortening of the overburden was diachronous across the study area, with salt anticlines starting to grow in the SW during Eocene, becoming younger and more deformed towards the NE (cf. SA4-6; Figure 6a and SA3; Figure 6b).

Our structural restoration in the north of the study area reconstructs the Late Cretaceous-Paleogene location of the salt anticlines, suggesting that their diachronous growth was again associated with salt flow and overburden translation over local base-salt highs (ii-iv; Figure 9c). More specifically, we see three key phases of anticline growth: (a) initiation due to the seaward flow of salt and its overburden over landward-dipping ramps in the Late Cretaceous-Early Eocene (ii; Figure 9c; cf. Figure 2a); (b) local extensional faulting of the anticlines in the Late Eocene as they translated across the seaward-dipping ramps (iii; Figure 9c; cf. position labelled 2; Figure 1c); and (c) further seaward translation of the anticlines, and formation of seaward-verging thrusts as the salt and its overburden passed over landward-dipping ramps during the Oligocene (iv, Figure 9c).

During the Miocene to Holocene, some pre-existing salt anticlines were locally influenced by contraction. For example, in the southwest, Middle Miocene strata onlap onto underlying strata and are dissected by outer-arc bending-related normal faults above salt anticlines, showing that, during MioceneHolocene translation, salt anticlines were laterally squeezed (SN1; Figures 5d and 6c and Table 2). We suspect that this squeezing may reflect the contraction of the salt anticlines at the base of the seaward-dipping ramps as they passed through the contractional hinge (cf. position labelled 3 in Figure 1b).

\subsection{Salt walls}

\subsection{1 | Geometry}

Salt walls broadly trend either parallel or oblique to NWto-N-trending ramps, being presently located above either the relatively flat parts of the base-salt or on landwarddipping ramps (SW and SS in Table 2, and SW1-3 and SS1; Figure 8a). There are three types of salt wall. The first type have a broadly symmetrical, triangular profile, a welldefined, pointed crest, and are flanked by inward-dipping, salt-detached normal faults, geometries characteristic of their formation in response to reactive diapirism initiated by overburden extension (SW1; Figure 5a; e.g. Vendeville \& Jackson, 1992a). In contrast with these morphologically and genetically simple reactive diapirs, we observe two additional types of rather more complex salt walls in the centre and northeast of the study area (SS1 and SW2; Figures 6c and 7).

The second type is represented by walls that vary in terms of their map-view trend and overall geometry, and which have variable spatial relationships with base-salt ramps (SW2; Figure 8a). In the centre and the south of the study area, SW2 trends parallel to and is presently located downdip of NW-trending, seaward-dipping ramps or relatively flat areas immediately seaward of these ramps (SW2; Figure 7b,c). Similar to the simple triangular salt walls described above, SW2 has a triangular profile and is flanked by inward-dipping, salt-detached normal faults. However, near its centre, SW2 has a rounded rather than pointed crest, whereas in the south, where the crest is pointed, the flanking faults have relatively shallow dips $\left(<50^{\circ}\right)$. Based on these geometrical characteristics, we infer that these walls initially formed as reactive diapirs, with their latter growth occurring in response to horizontal shortening (e.g. Vendeville \& Jackson, 1992b). This shortening drove roof arching, rounding-off of the diapir crest and the passive rotation of normal faults to lower dips. The northern end of SW2 presently trends parallel to and is located above-to-slightly downdip of, a seaward-dipping ramp (SW2; Figure 7a). Here, SW2 is capped by an irregular, indented crest, which is associated with a salt horn (SW2; Figure 5d). By comparison to geometries formed in physical models, we infer that this distinctive structural style formed in response to extension-driven diapir fall. This fall was possibly related to the flow of salt along strike within the wall to feed another part of the structure that was actively rising in response to synchronous shortening (e.g. Vendeville \& Jackson, 1992a).

The third type of salt wall is represented by structures trending parallel to, and presently located above or slightly downdip of NW-trending, seaward-dipping ramps, or the relatively flat areas immediately seaward of these ramps (SS1-3; Figure 8a). At its northern end, SS1 is presently located above a relatively flat part of the base-salt. In this location, SS1 is flanked by inward-dipping faults overlying a triangular salt pedestal, an incomplete secondary weld (sensu Wagner \& Jackson, 2011), and an arched roof (Figure 6c), features characteristic of a reactive diapiric wall that was subsequently squeezed (see Dooley et al., 2009; Jackson et al., 2008; Rowan et al., 2004; Vendeville \& Nilsen, 1995). We observe another two walls of this complex type in the northeast of the study area; these structures, which are separated by a primary weld and which overlie a NW-trending, seaward-dipping ramp, are both geometrically 
similar to SS1, but are both characterized by thrusted roofs (Table 3 and SS2-3; Figure 7a). Here, at the base of this ramp, SS2 is characterized by a very well-defined triangular profile, is flanked by inward-dipping faults, and a NWSE-striking, landward-dipping thrust above its crest (SS2; Figure 7a). However, further to the northwest, SS2 appears to be overlain by outer-arc extensional faults, being located above a rollover monocline (see Figure $6 \mathrm{~b}$ and Table 3). Thrusts, similar to those observed further to the southeast, are lacking. Based on these characteristics we suggest that the monocline formed due to draping of overburden across the western flank of the SS2, which originally formed as a reactive diapir. This folding induced the formation of outerarc bending-related normal faults in the roof of SS2; the structure and its overburden were subsequently shortened, and related faults reactivated to form the crestal fore-thrust.

\subsection{2 | Timing and structural evolution}

The age of growth strata indicate that salt walls began to grow in the Eocene to Oligocene. For example, Late Cretaceousto-Eocene strata locally onlap onto underlying (Albian) strata and fill RSBs (Figure 7b,c) or thicken across reactive diapir-flanking faults (SW1; Figure 5a and SW2; Figure 7a). Oligocene growth strata are also locally contained in RSBs. Locally, however, Late Cretaceous-to-Oligocene strata are tabular adjacent to and upturned against diapir flanks, suggesting these structures are younger and that reactive diapir growth was diachronous (SS2, SS3; Figure 7a and SW2; Figure $7 b, c)$.

The structural restorations show that in the north and the south of the study area, Albian salt anticlines had by the Eocene-Oligocene, translated seaward onto either the flattopped structural highs or seaward-dipping ramps, resulting in crestal extension and the formation of reactive salt walls (SW2 and SS2-3 in iii-iv; Figure 9a,b). Based on our restorations, we propose two mechanisms that may have caused local overburden extension and reactive diapir rise. First, an increase in the velocity of the seaward flow above the local structural high resulted in the widening of a pre-existing salt anticline, and the formation of extensional faults in its overburden (location labelled 1; Figure 1c; see late-stage buildup of thick salt body above high block of Jackson \& Hudec, 2017; see also Dooley et al., 2017, 2018). Second, the seaward flux of salt was retarded as salt flowed across the upper hinge of the seaward-dipping ramp, resulting in overburden extension (location labelled 2; Figure 1c; see extensional hinge of Jackson \& Hudec, 2017; see also Dooley et al., 2017, 2018). Our key interpretation is that seawardtranslating, pre-existing anticlines underwent subsequent extension to become reactive diapirs in the Late CretaceousOligocene. Local contraction did occur in the Oligocene, as evidenced by local arching and thinning of Oligocene strata over walls like SS1 (Figure 6c). We suggest that this contraction was driven by translation of the walls towards the lower hinge of the seaward-dipping ramps, where they encountered relatively thick, slower-moving salt (location labelled 3; Figure 1c; see contractional hinge of Jackson \& Hudec, 2017; see also Dooley et al., 2017, 2018).

By the Miocene, salt and its overburden had translated a significant distance seaward (11-21 km; Figure 10); this is comparable to the distance calculated by Evans and Jackson (2019; i.e. $18 \mathrm{~km}$ ) based on their study of ramp-syncline basins in the SE of the study area. This translation is recorded in the formation of RSBs and resulted in the continuous growth and/or local contraction of pre-existing diapirs as they passed over base-salt relief (Figures 6 and 7).

During the Early-Middle Miocene, SS2 and SS3 continued to grow, before they are shortened and squeezed at the end of the Middle Miocene. Continued reactive growth of these walls is indicated by presence of an upturned collar of EarlyMiddle Miocene growth strata that thicken across flanking, salt-detached normal faults (SS2-3; Figure 7a). Subsequent shortening is recorded by the erosional truncation of Middle Miocene strata across the diapir crest.

The structural restoration shows that, during the EarlyMiddle Miocene, pre-existing (reactive) salt walls continued to grow (SS2-3 in v; Figure 9b). We speculate that the continued growth of these walls was influenced by local extensions above the seaward-dipping ramps (c.f. location labelled 2; Figure 1c). Furthermore, at the end of the Middle Miocene, whereas some salt walls continued to grow, SS2 continued translating seaward before undergoing contraction at the base

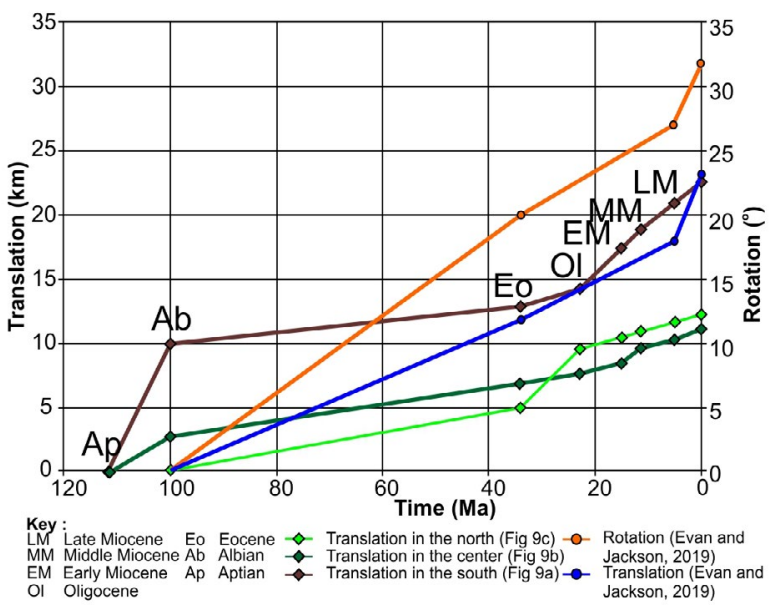

F I G URE 10 Graph showing the cumulative horizontal translation of salt an overburden in each of the cross-sections shown in Figure 9. The cumulative translation (i.e. the left vertical scale) are recorded in each absolute time (i.e. horizontal scale) from the seismic stratigraphic horizon. These cumulative translations are compared with the cumulative translation (i.e. the left vertical scale) and rotation (i.e. the right vertical scale) of Evans and Jackson (2019) 
of a seaward-dipping ramp, reverse reactivating the former salt-detached normal fault responsible for its initial growth, and resulting in the formation of a fore-thrust (vi; Figure 9b; c.f. location labelled 3; Figure 1c).

During the Late Miocene, SS2 and SS3 continued shortening. This shortening is recorded by thinning of Upper Miocene strata across the thrust-bound block capping the diapirs (SS2-3; Figure 7a). Our structural restoration suggest that a primary weld formed above a local structural high at this time, with SS2 and SS3 were being squeezed at the base and top, respectively, of the underlying seawarddipping base-salt ramp (vii; Figure 9b). At the base of the ramp, squeezing caused rotation and welding of the eastern flank of the SS2, whereas further updip this caused reverse reactivation of a salt-detached normal fault above SS3, such that it now resembles a back-thrust. Three possible mechanisms might account for generating local contraction and this change in structural style during the Late Miocene. The first is retardation of the seaward flow of salt as it encounters local base-salt highs; this could have caused salt thickening, overburden shortening, and fault inversion (see Ferrer et al., 2017). However, this interpretation is considered unlikely because, from this point northwestward, salt-detached normal faults rather than thrusts are presently observed above many salt structures (Figures $6 \mathrm{~b}$ and $8 \mathrm{~b}$ ). As such, the local base-salt high does not appear to have driven the repeated inversion of normal faults to form back-thrust as the salt structures translated seaward above seaward-dipping ramps. The second mechanism might reflect slowing of salt and shortening of its overburden as they travel onto a seawarddipping ramp (c.f. location labelled 3; Figure 1c). Although this mechanism may reasonably explain the generation of the fore-thrust, it is considered unlikely as a sole mechanism because local contraction above seaward-dipping ramps has not been documented in physical models; i.e. salt flow onto a seaward-dipping ramp induces contraction rather than extension (location labelled 2; Figure 1c; Dooley et al., 2017, 2018; Jackson \& Hudec, 2017).

Given the spatial relationship between base-salt structures, salt walls, and supra-salt faults during the Late Miocene, inferred from our structural restorations, we suggest that shortening and thrusting were driven by a combination of the salt slowing, overburden shortening and primary welding above the seaward-dipping ramp (vii; Figure 9b). We interpret that whereas the growth of the fore-thrust (i.e. above the SS2) was associated with local contraction at the base of the ramp, the updip weld act as a buttress that inhibited further seaward flow of salt, resulting in overburden shortening and inversion of the former salt-detached normal fault (i.e. above the SS3). Our interpretation is consistent with the predictions of physical models, which indicate that salt pinch-out above seaward-dipping ramps can induce overburden shortening and thrusting (c.f. Dooley et al., 2007).
During the Miocene, SW2 was subjected to active rise in the south of the study area and extension-driven fall in the centre. In the south, active rise initiated in the Early Miocene; this is indicated by the onlap of Early Miocene strata onto Oligocene strata adjacent to SW2 (Figure 7b,c). Active rise continued during the Middle-Late Miocene, as reflected by overall thinning of upturned Middle-Late Miocene strata against the diapir flank. In the central part of the study area, however, extension-driven fall initiated in the Middle Miocene, as indicated by the Middle Miocene strata draping over a relic horn at the crest of the northern margin of SW2 (Figure 5d). Extension-driven fall continued into the Late Miocene, as indicated by thickening of Late Miocene strata across normal faults in the diapir roof (SW2; Figures 5d and 7a).

Our structural restorations across the central and southern parts of the study area highlight the Miocene development of SW2. In the south, SW2 underwent active rise as it entered a contractional strain field at the base of a seaward-dipping ramp (v-vii; Figure 9a). In contrast, at its centre, SW2 underwent initially extension-driven reactive rise as the diapir travelled onto a seaward-dipping ramp and went through the extensional hinge, and then extension-driven fall (v-vii; Figure 9b). We suggest that diapir fall was associated with the along-strike flow of salt from the northern part of SW2 in the centre to feed actively rising portions of the wall in the south (see also Vendeville \& Jackson, 1992b).

By the Pliocene-Recent, some walls were inactive and completely buried, whereas others continued to grow via shortening-induced active diapirism or extension-driven reactive diapirism. Synchronous shortening and extension is well-illustrated in the centre of the study area, where Pliocene-to-Recent growth strata thin onto an inversionrelated fold above SS3, whilst similar-age strata thicken across the salt-detached normal faults on the eastern flank of the SW2 (Figure 7a). In the south, however, Pliocene-toRecent strata are folded and eroded above SW2, with Late Miocene strata presently exposed at the seabed (Figure 7b). This observation indicates that locally at least, SW2 continues to actively rise. This is likely driven by ongoing translation, an interpretation consistent with the observation that Pliocene-to-Recent strata fill still-active RSBs (Figure 7b; see also Evans \& Jackson, 2019).

\section{7 | TRANSLATION MAGNITUDE AND THE TECTONIC EVOLUTION OF THE MID-SLOPE DOMAIN, OUTER KWANZA BASIN}

We here link our detailed analysis of the geometry and evolution of salt-related structures and sub-regional structural restorations with the RSB-determined, rotation magnitude estimates of Evans and Jackson (2019; Figure 10) to generate 

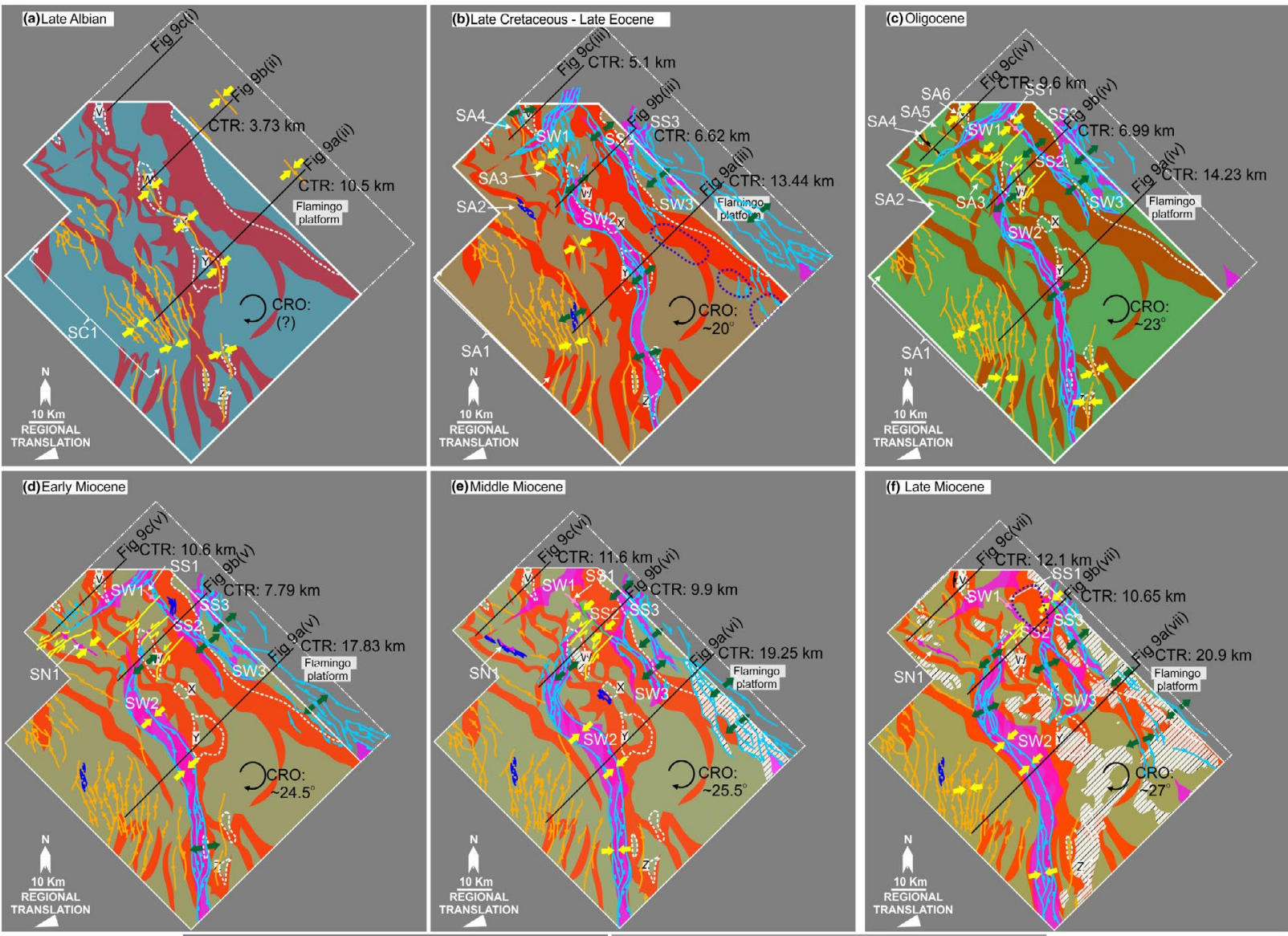

\section{(e) Middle Miocene}
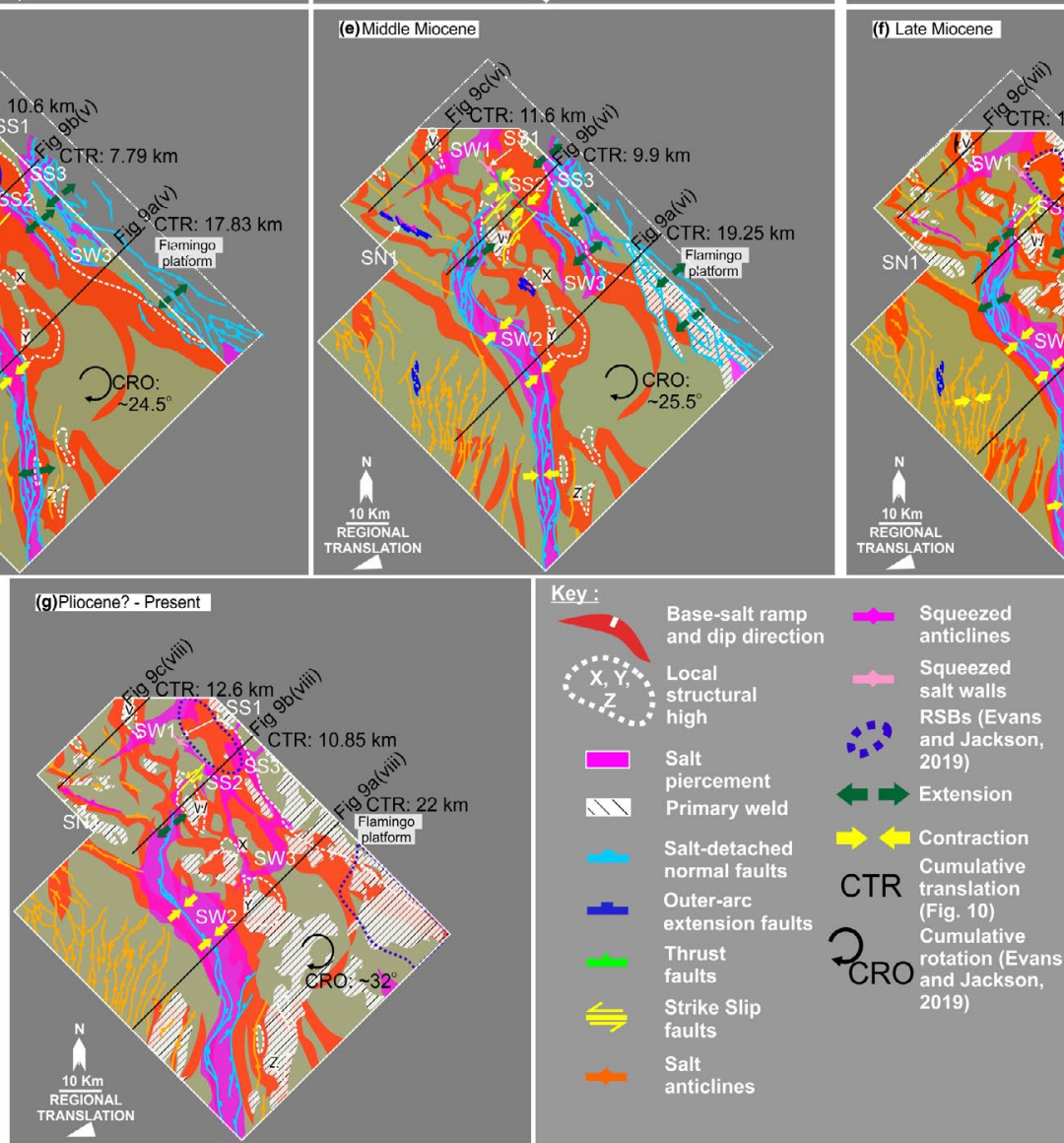

F I G U RE 11 Map-view schematic restorations of salt and overburden structures from (a) the Late Albian to (g) Present; this is based on time-constrained horizontal translation magnitudes presented in the structural restorations shown in Figures 9 and 10, and information on RSB-constrained, salt and overburden rotations presented by Evans and Jackson (2019; see text for full description; see also Appendix S2 for methodologies)

seven sequential maps illustrating the three-dimensional, salttectonic evolution of the mid-slope domain of this segment of the Outer Kwanza Basin, offshore Angola (Figure 11). These maps show the initial (i.e. Early Albian) location of salt and supra-salt structures relative to base-salt features, and their subsequent evolution as they translated seaward. For ease of description, these maps are grouped into three main salttectonics phases (i.e. Early Cretaceous, Late CretaceousPaleogene, and Neogene-Present).

\section{1 | Early Cretaceous}

The Early Cretaceous was characterized by base-salt reliefinduced folding of the overburden in the south and centre due to spatial and temporal variations in the magnitude and thus rate of seaward translation; i.e. the magnitude was ca. 3.7 and $10.5 \mathrm{~km}$ in the centre and south, respectively (Figures 10 and 11a). In contrast and as indicated by the presence of tabular Albian strata, the northern domain did not translate or 
undergo significant salt tectonics at this time (i; Figures 9c and 10). The cause of this along-strike variability is not obvious, but it might reflect the fact that Aptian salt was thicker (von Nicolai, 2011) and, therefore, possibly faster flowing in the south (Evans \& Jackson, 2019). Regardless of the cause, we speculate that this variability led to the salt and its overburden being mildly sheared and/or undergoing bulk, rigidbody, clockwise rotation (Figure 11a).

\section{2 | Late Cretaceous-Paleogene}

The Late Cretaceous-Paleogene was dominated by reactive diapirism and salt wall formation, with this being particularly common in the centre and the northeast due to increasing salt flow velocity above either local structural highs (i.e. flat-topped) or the outer-edge of the Flamingo Platform (i.e. seaward-dipping ramps; Figure 11b,c). Local shortening in the north initiated the growth of salt anticlines above the landward-dipping ramps, and in the southwest, where the precursor anticlines amplified as they rotated across concave-into-the basin, seaward-dipping ramps. Anticline rotation due to along-strike variations in seaward salt flux meant that these structures presently have a wide range of trends (cf. convergent gliding pattern of Cobbold \& Szatmari, 1991). Anticline tightening initiated the growth of outer-arc bending-related normal faults in their roofs.

Synchronous extension-driven diapirism and contractiondriven salt-detached folding reflect spatial differences in the rate of seaward translation of the salt and its overburden. More specifically, during the Oligocene, the total magnitude of the translation in the north, where translation did not occur until the Eocene, surpassed that in the centre, where translation started earlier (i.e. Late Albian; Figure 10). In the north, along-strike variations in the magnitude of translation were accommodated by the local growth of strike-slip faults that are particularly well-developed in the north (Figure 5a, and Table 3). In the south, the variation in the translation magnitude resulted in more distributed strain in the form of seemingly bulk overburden rotation in the SE (i.e. $23^{\circ}$; Evans \& Jackson, 2019; Figure 11c). Overburden rotation occurred because the seaward flow of salt slowed across local structural highs in the centre of the study area, whilst salt was able to flow faster in the southeast, an area of relatively subdued relief (Figure 12; cf. convergence of salt flow across isolated structural highs; Dooley et al., 2018).

\section{3 | Neogene-present}

Along strike variation in translation magnitude, as well as synchronous extension and contraction driven by salt flow across base-salt relief, continued into the Neogene. Variations in translation magnitude are clearly shown in the Miocene, when the translation rate was relatively stable in the north but accelerated in the centre and south (Figure 10). These variations likely reflect along-strike changes in salt thickness, and the interaction between the salt, its overburden, and underlying base-salt relief. In the southwest, outerarc bending-related normal faults formed at the crest of salt anticlines due to shortening and tightening of the precursor anticlines (SA1; Figures 5b, 11d-f). This shortening can be attributed to the relatively late, upslope migration of contraction that continues to the present (Brun \& Fort, 2004; Fort et al., 2004). However, where anticlines were located above relatively flat areas of the base-of-salt immediately seaward of concave-into-the-basin, seaward-dipping ramps, we propose that anticline shortening was driven by convergent gliding (c.f. Cobbold \& Szatmari, 1991). From this point northward and northeastward, squeezing and active rise of pre-existing walls and anticlines occurred, either at the base or top of seaward-dipping ramps (Figure 11d-f). At the same time, local extension induced reactive piercement of the overburden, resulting in the formation of rollers and rafts above the ramp defining the seaward-edge of the Flamingo Platform (vi; Figures 9a and 11e). These local, short length-scale variations between contractional and extensional structures reflect disparities in the magnitude and rate of seaward translation of the salt and its overburden, with this again being accommodated in the north by strikeslip faulting, and in the east by the bulk rotation of the salt and its overburden. Salt tectonics is presently modest in the mid-slope domain, and most salt and supra-salt structures are buried and inactive. Locally, however, active diapiric rise and deformation of the seabed attest to ongoing shortening (Figure 11g).

Our structural restorations suggest that the total absolute translation magnitude varied along-strike of this segment of this salt-based passive margin (i.e. 13, 11, and $22 \mathrm{~km}$ in the north, centre, and south, respectively; Figure 10). These values are generally less than those calculated by Evans and Jackson (2019) based on their analysis of RSBs and flanking salt walls located SE of the present study area (i.e. $23 \mathrm{~km}$ ). We suggest two interpretations might plausibly account for the differences in these magnitude values: (a) salt was originally thicker(ca. $1.3 \mathrm{~km}$ ) in the SE, meaning the salt and its overburden flowed seaward relatively quickly compared to the NW (Evans \& Jackson, 2019; von Nicolai, 2011); (b) the relief at base-salt varied along strike, being large in the north and centre where the translation magnitude was relatively small, and more subdued in the south where the magnitude was relatively large; in this interpretation, regional variations in salt thickness are less important (Figures 4a and 5a; see Dooley et al., 2017; Dooley \& Hudec, 2017). 
(a)
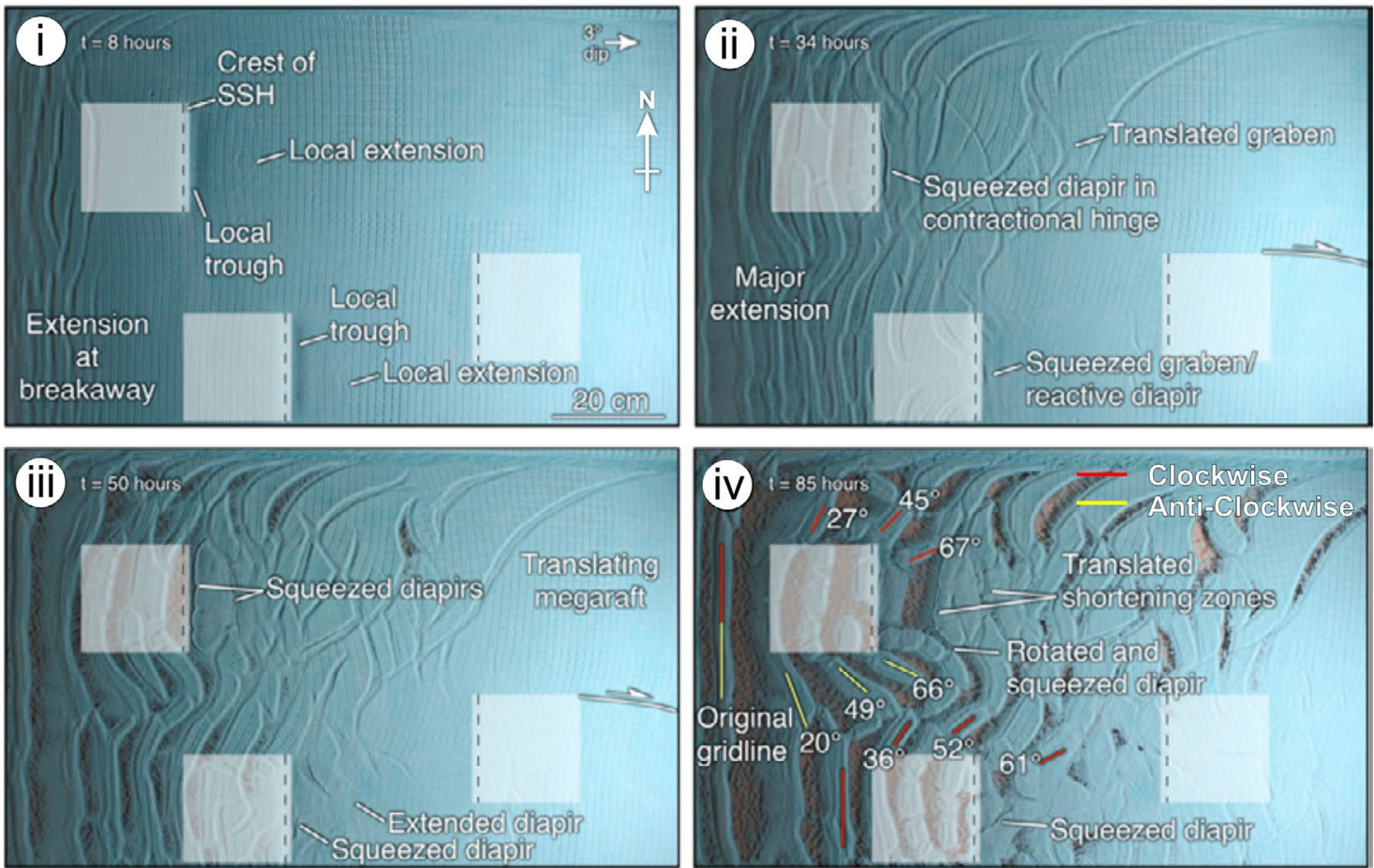

(b)
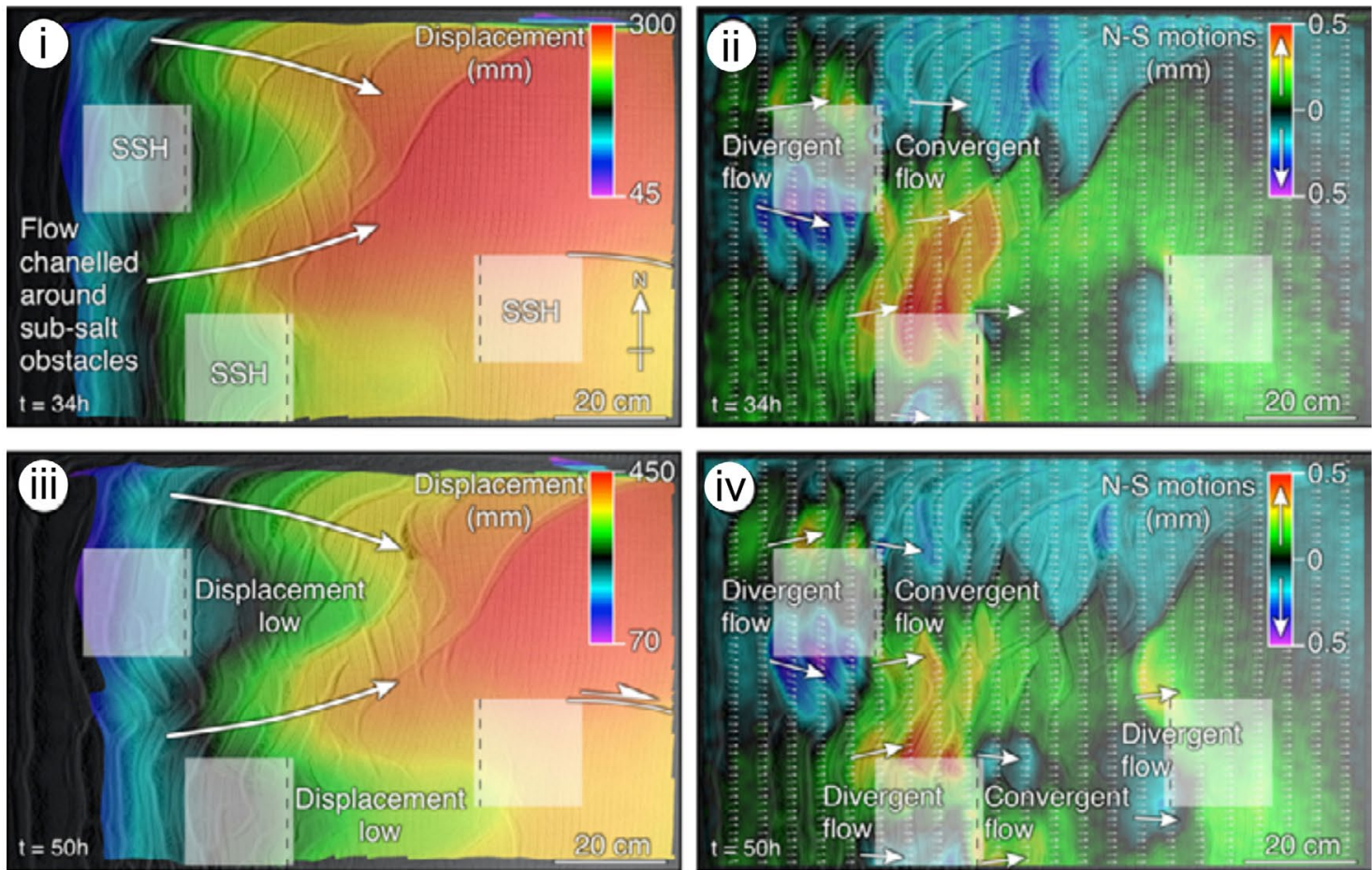

F I G U R E 12 Physical model investigating the effects of a local sub-salt high block (SSH) on the down-dip (i.e. to-the-right) flow of salt, illustrating the range of salt and overburden structures that can form (from Dooley et al., 2018). This situation is similar to that observed on many salt-bearing passive margins, including the Outer Kwanza Basin, offshore Angola (i.e. compare with the sub-salt high blocks V-Z observed in Figure 4a). (a) Overhead photographs of the models at various time steps (i-iv) showing the variable distribution and overprinting of extensional and contractional salt and overburden structures, and rotation of salt and overburden structures at the up-dip (up to $36^{\circ}$ ) and down-dip (up to $67^{\circ}$ ) edge of the SSHs; and (b) the local base-salt high act as salt flow perturbation, resulting in salt flow channelization (i.e. convergent and divergent flow). For full details of the model design and set-up, please see Dooley et al. (2018) 


\section{8 | DISCUSSION}

Classic models of salt-bearing passive margins state that saltrelated deformation above relatively smooth base-salt relief are related to the kinematically-linked domains of updip extension, mid-slope translation, and downdip contraction (e.g. Brun \& Fort, 2004, 2011; Hudec \& Jackson, 2004; Marton et al., 2000; Rowan el al., 2004). This model cannot, however, explain the wide range of local patterns and styles of predominantly contraction-related salt structures seen on the mid-slope of the Outer Kwanza Basin, offshore Angola. Here, the mid-slope domain is characterized by the synchronous formation of extensional and contractional salt-related structures. Evans and Jackson (2019) invoked spatially complex salt flow over base-salt relief to explain this spatially complex pattern of deformation southeast of the present study area, illustrating the formation, translation and rotation of RSBs and flanking salt walls. They highlight the key role played by the seaward-edge of the Flamingo Platform but they did not focus on the types and kinematics of contraction-related salt-tectonic structures. We show that local base-salt relief, and not only the Flamingo Platform, control the diversity and evolution of salt-related contractional styles in the mid-slope domain of the Outer Kwanza Basin. Similar relationships are documented in the Santos and Campos Basins, offshore Brazil and in the Gulf of Mexico (e.g. Dooley \& Hudec, 2017; Dooley et al., 2017; Pichel et al., 2019).

Several physical models explore the relationship between base-salt relief and salt tectonics, suggesting that salt flow across rugose relief, coupled with the formation of salt welds, can influence structural style. For example, Cobbold and Szatmari (1991) illustrate that salt flow across convex- and concave-towards-the-basin base-salt relief can generate arcuate arrays of extensional or contractional structures, respectively. More recently, Dooley et al. $(2017,2018)$ illustrate that salt flow and overburden across landward- and/or seawarddipping ramps at base-salt can generate coeval contractional and extensional structures in areas otherwise dominated by simple horizontal translation (Figure 1a,c). These models also show that deformation patterns can become especially complex where the base-salt relief is discontinuous along-strike (Figure 12a). These local discontinues act to locally perturb salt flow, resulting in salt flow channelization (i.e. convergent and/or divergent) that can cause the salt and its overburden to rotate as they translate seaward (Figure 12b). Other physical models by Dooley et al. (2007) show that salt may locally weld at the base of salt-detached thrusts during bulk shortening, resulting in increasing frictional drag along the saltoverburden interface. As shown by Duffy et al. (2019), salt welds such as this may causes otherwise freely horizontally translating minibasins to collide, inducing the formation of contractional structures.
Our study seismic reflection-based study of the midslope domain of the Outer Kwanza Basin allow us to test the predications of several physical models. Our observations, combined with our structural restorations, illustrate that the interaction between predominantly horizontally flowing salt and underlying base-salt relief resulted in complex strains. More specifically, contraction structures developed in the midst of an array of extensional structures, with mainly structures undergoing a multiphase history comprising both periods of extension and compression. For example, the translation of salt and its overburden across broadly marginparallel ramps (i.e. NW and N-trending) causes not only early contraction and the formation of salt anticlines when salt was capped by a relatively thin roof, but also late extension and shortening of precursor salt structures (i.e. squeezing reactive and active rise of diapirs) as they are translated over multiple ramps (cf. Cobbold \& Szatmari, 1991; Dooley et al., 2017, 2018).

Our study shows that the formation of mid-slope contractional structures is made even more complex due to the combined effect of bulk rotation (i.e. a type of distributed shear) of the salt overburden and pre-existing salt structures. Previous studies using 3D seismic reflection data suggest that this rotation may be caused by salt flow across complex base-salt relief (i.e. isolated base-salt highs and/or convexand concave-into-the-basin ramps; Pichel et al., 2019), and/ or spatial variations in the original salt thickness (Evans \& Jackson, 2019). The results of our study are consistent with the latter hypothesis, but we also suggest that a key control on salt structure and overburden rotation is the presence of local base-salt relief (i.e. rotation only occurred in the south of the study area, where base-salt relief was more subdued). The broadly complex ramps and isolated base-salt highs in the north and centre of the study area perturbed seaward flow of salt and its overburden (cf. Figure 12; Dooley et al., 2018), resulting in salt flowing faster in the south. Concave-ramps in the southwest also served to amplify and rotate contractional structures as they translated seaward (cf. convergent gliding; Cobbold \& Szatmari, 1991).

Primary and secondary salt welds formed in the mid-slope domain of the Outer Kwanza Basin during horizontal translation (cf. Dooley et al., 2007). The primary welds formed above seaward-dipping ramps, driving local squeezing of preexisting extensional diapirs (walls) located on their updip, landward side. The process described here is similar to that described from the Northern Gulf of Mexico, where primary welding causes otherwise freely horizontally translating minibasins to collide, inducing the formation of contractional structures (see Duffy et al., 2019). In our study, weld-induced compression results in the reverse reactivation of previously extensional structures (i.e. normal faults) that initially formed near the upper hinge of seaward-dipping ramps (position labelled 2; Figure 1c). 
We argue that using the geometry and evolution of RSBs alone to understand the kinematics of salt-detached deformation yields an incomplete picture (e.g. Evans \& Jackson, 2019; Pichel et al., 2018); such analyses should be supported by the detailed mapping of base-salt relief and overlying salt-tectonic structures. For example, rather than simply being associated with bulk clockwise rotation of the overburden (Evans \& Jackson, 2019), we observe that RSBs are locally associated with the local growth of salt-detached strike-slip faults (i.e. a type of focused shear), at least in the northern part of the basin during the Late Miocene to Present (Figure 11f,g). The formation of strikeslip faults record spatial differences in the rate and magnitude of the seaward translation of salt and its overburden, with this effect maybe being either enhanced or retarded by the presence of base-salt relief. Where such relief is present, along-strike variations in translation may be relatively sharp, leading to focused shear and strike-slip faulting. Further work is required to establish the detailed geometric and kinematic relationship between salt-detached strike-slip faults and base-salt relief.

\section{9 | CONCLUSION}

We used 3D seismic reflection data to examine the structural style, distribution, and kinematics of salt structures in the mid-slope domain of the Outer Kwanza Basin, offshore Angola. We showed that a suite of predominantly contractional salt-related structures, including salt anticlines and squeezed walls, as well as salt-detached thrusts, are observed in the midst of an array of extensional structures. These salt-related structures trend either parallel or oblique to, and are sometimes located directly above, NW-, N-, NEtrending ramps along the base-salt. Some of the structures are separated by either apparent or incomplete primary salt welds.

Using section restorations to identify the pre-translation location of the salt and salt-related structures, we argue that base-salt relief and the formation of primary salt welds controlled the presence and evolution of contractional saltrelated structures. We also show that the seaward translation of salt and its overburden began in the Albian, soon after salt deposition, and that the absolute magnitude of translation varied from 13 to $22 \mathrm{~km}$. The interaction between base-salt highs and salt welds, and the seaward-translating salt structures lead to locally intense overprinting of extensional and compressional strain fields. Seaward translation was also associated with bulk clockwise rotation of salt structures and related overburden structures. We suggest that during early translation, this rotation was driven by regional, along-strike changes in salt thickness, with thicker, faster-flowing salt and overburden in the SE and thinner, slower-moving salt and overburden in the NW. However, during later translation, as salt had locally thinned due to the flow of salt into growing diapirs, base-salt relief became relatively more important; i.e. in the north and centre, where base-salt relief was more pronounced, the seaward translation of salt and its overburden translation was more tortuous and overall slower compared to the south.

Our study can help improve our understanding of the styles and origin of salt-related deformation that can occur in salt basins. More specifically, our study further highlights the key role base-salt relief, salt thickness variations, and salt welding can play in driving surprisingly complex deformation in the mid-slope domain of salt basins. These learning can be applied to other salt basins and especially salt-detached passive margins.

\section{ACKNOWLEDGEMENT}

We thank Stefan Back, Mar Moragas and Juan Soto for their encouraging, critical and constructive reviews that substantially improved our initial submission. We also wish to thank Sian Evans, Leonardo Pichel and Alexander Coleman for discussions during the course of this study. A big thank you to CGG for providing access to the high-quality 3D seismic dataset and for allowing publication of the results of this study. The main author thank the Indonesia Endowment Fund for Education (LPDP) for sponsoring his $\mathrm{PhD}$ research. The main author thank Benyamin Sapiie, Keigo Kitamura, Igna Hadi Suparyanto and Indonesian Institute of Science (LIPI) for indirect assistance and administrative support in his $\mathrm{PhD}$ research. The authors also acknowledge Schlumberger for providing Petrel software and Petroleum Experts (Petex) for provision of a licence for 2D Move software to Imperial College.

\section{Peer Review}

The peer review history for this article is available at https:// publons.com/publon/10.1111/bre.12539.

\section{DATA AVAILABILITY STATEMENT}

The seismic data supporting the findings of this study are available from CGG. However, restrictions apply to the availability of these data, which were used under license for this study.

\section{ORCID}

Aurio Erdi (D) https://orcid.org/0000-0003-4247-715X

Christopher A.-L. Jackson (iD https://orcid.

org/0000-0002-8592-9032

\section{REFERENCES}

Brownfield, M. E., \& Charpentier, R. R. (2006). Geology and total petroleum systems of the West-Central Coastal Province (7203), West Africa. U.S. Geological Survey Bulletin, 2207-B, 52. 
Brun, J.-P., \& Fort, X. (2004). Compressional salt tectonics (Angolan margin). Tectonophysics, 382(3-4), 129-150.

Brun, J.-P., \& Fort, X. (2011). Salt tectonics at passive margins: Geology versus models. Marine and Petroleum Geology, 28(6), 1123-1145.

Brun, J.-P., \& Mauduit, T. P. O. (2009). Salt rollers: Structure and kinematics from analogue modelling. Marine and Petroleum Geology, 26(2), 249-258.

Cobbold, P. R., \& Szatmari, P. (1991). Radial gravitational gliding on passive margins. Tectonophysics, 188(3-4), 249-289.

Cramez, C., \& Jackson, M. P. A. (2000). Superposed deformation straddling the continental-oceanic transition in deep-water Angola. Marine and Petroleum Geology, 17(10), 1095-1109.

Davison, I., Anderson, L., \& Nuttall, P. (2012). Salt deposition, loading and gravity drainage in the Campos and Santos salt basins: Geological Society. London, Special Publications, 363(1), 159-174.

Dooley, T. P., \& Hudec, M. R. (2017). The effects of base-salt relief on salt flow and suprasalt deformation patterns - Part 2: Application to the eastern Gulf of Mexico. Interpretation, 5, SD25-SD38.

Dooley, T. P., Hudec, M. R., Carruthers, D., Jackson, M. P. A., \& Luo, G. (2017). The effects of base-salt relief on salt flow and suprasalt deformation patterns - Part 1: Flow across simple steps in the base of salt. Interpretation, 5, SD1-SD23.

Dooley, T. P., Hudec, M. R., Pichel, L. M., \& Jackson, M. P. A. (2018). The impact of base-salt relief on salt flow and suprasalt deformation patterns at the autochthonous, paraautochthonous and allochthonous level: Insights from physical models. Geological Society, London, Special Publications, 476, SP476.413.

Dooley, T. P., Jackson, M. P. A., \& Hudec, M. R. (2007). Initiation and growth of salt-based thrust belts on passive margins: Results from physical models. Basin Research, 19(1), 165-177.

Dooley, T. P., Jackson, M. P. A., \& Hudec, M. R. (2009). Inflation and deflation of deeply buried salt stocks during lateral shortening. Journal of Structural Geology, 31(6), 582-600.

Duffy, O. B., Fernandez, N., Peel, F. J., Hudec, M. R., Dooley, T. P., \& Jackson, C. A. L. (2019). Obstructed minibasins on a salt-detached slope: An example from above the Sigsbee canopy, northern Gulf of Mexico. Basin Research, 32(3), 505-524.

Duval, B., Cramez, C., \& Jackson, M. P. A. (1992). Raft tectonics in the Kwanza Basin, Angola. Marine and Petroleum Geology, 9(4), 389-404.

Evans, S. L., \& Jackson, C. A. L. (2019). Base-salt relief controls saltrelated deformation in the Outer Kwanza Basin, offshore Angola. Basin Research, 32(4), 668-687.

Ferrer, O., Gratacós, O., Roca, E., \& Muñoz, J. A. (2017). Modeling the interaction between presalt seamounts and gravitational failure in salt-bearing passive margins: The Messinian case in the northwestern Mediterranean Basin. Interpretation, 5(1), SD99-SD117.

Fort, X., Brun, J.-P., \& Chauvel, F. (2004). Salt tectonics on the Angolan margin, synsedimentary deformation processes. AAPG Bulletin, 88(11), 1523-1544.

Gaullier, V., Brun, J. P., Guerin, G., \& Lecanu, H. (1993). Raft tectonics: The effects of residual topography below a salt de'collement. Tectonophysics, 228(3-4), 363-381.

GEBCO Compilation Group (2020). The GEBCO_2020 Grid - a continuous terrain model of the global oceans and land, British Oceanographic Data Centre, National Oceanography Centre. NERC. https://www.bodc.ac.uk/
Guiraud, M., Buta-Neto, A., \& Quesne, D. (2010). Segmentation and differential post-rift uplift at the Angola margin as recorded by the transform-rifted Benguela and oblique-to-orthogonal-rifted Kwanza basins. Marine and Petroleum Geology, 27(5), 1040-1068.

Hudec, M. R., \& Jackson, M. P. A. (2002). Structural segmentation, inversion, and salt tectonics on a passive margin: Evolution of the Inner Kwanza Basin, Angola. Geological Society of America Bulletin, 114(10), 1222-1244. https://doi.org/10.1130/00167606(2002)114<1222:SSIAST>2.0.CO;2

Hudec, M. R., \& Jackson, M. P. A. (2004). Regional restoration across the Kwanza Basin, Angola: Salt tectonics triggered by repeated uplift of a metastable passive margin. AAPG Bulletin, 88(7), 971-990. https://doi.org/10.1306/02050403061

Jackson, C. A. L., Jackson, M. P. A., \& Hudec, M. R. (2015). Understanding the kinematics of salt-bearing passive margins: A critical test of competing hypotheses for the origin of the Albian Gap, Santos Basin, Offshore Brazil. Geological Society of America Bulletin, 127(11-12), 1730-1751. https://doi.org/10.1130/B31290.1

Jackson, M. P. A., \& Hudec, M. R. (2005). Stratigraphic record of translation down ramps in a passive-margin salt detachment. Journal of Structural Geology, 27(5), 889-911. https://doi.org/10.1016/j. jsg.2005.01.010

Jackson, M. P. A., \& Hudec, M. R. (2009). Interplay of basement tectonics, salt tectonics, and sedimentation in the Kwanza Basin, Angola. AAPG.

Jackson, M. P. A., \& Hudec, M. R. (2017). Salt tectonics: principles and practice. Cambridge University Press.

Jackson, M. P. A., Hudec, M. R., Jennette, D. C., \& Kilby, R. E. (2008). Evolution of the cretaceous astrid thrust belt in the ultradeep-water lower Congo Basin, Gabon. AAPG Bulletin, 92(4), 487-511. https:// doi.org/10.1306/12030707074

Karner, G. D., \& Driscoll, N. W. (1999). Tectonic and stratigraphic development of the West African and eastern Brazilian Margins: Insights from quantitative basin modelling. Geological Society, London, Special Publications, 153(1), 11-40. https://doi.org/10.1144/GSL. SP.1999.153.01.02

Karner, G. D., Driscoll, N. W., \& Barker, D. H. N. (2003). Syn-rift regional subsidence across the West African continental margin: The role of lower plate ductile extension. Geological Society, London, Special Publications, 207(1), 105-129. https://doi.org/10.1144/ GSL.SP.2003.207.6

Lundin, E. R. (1992). Thin-skinned extensional tectonics on a salt detachment, northern Kwanza Basin, Angola. Marine and Petroleum Geology, 9(4), 405-411. https://doi. org/10.1016/0264-8172(92)90051-F

Marton, L. G., Tari, G. C., \& Lehmann, C. T. (2000). Evolution of the Angolan passive margin. West Africa, with emphasis on postsalt structural styles. Atlantic Rifts and Continental Margins, 115, 129-149.

Moulin, M., Aslanian, D., Olivet, J.-L., Contrucci, I., Matias, L., Géli, L., Klingelhoefer, F., Nouzé, H., Réhault, J.-P., \& Unternehr, P. (2005). Geological constraints on the evolution of the Angolan margin based on reflection and refraction seismic data (ZaïAngo project). Geophysical Journal International, 162(3), 793-810.

Peel, F. J. (2014). The engines of gravity-driven movement on passive margins: Quantifying the relative contribution of spreading vs. gravity sliding mechanisms. Tectonophysics, 633, 126-142.

Pichel, L. M., Jackson, C. A. L., Peel, F., \& Dooley, T. P. (2019). Basesalt relief controls salt-tectonic structural style, São Paulo Plateau, Santos Basin, Brazil. Basin Research, 32(3), 453-484. 
Pichel, L. M., Peel, F., Jackson, C. A. L., \& Huuse, M. (2018). Geometry and kinematics of salt-detached ramp syncline basins. Journal of Structural Geology, 115, 208-230.

Quirk, D. G., Schødt, N., Lassen, B., Ings, S. J., Hsu, D., Hirsch, K. K., \& Von Nicolai, C. (2012). Salt tectonics on passive margins: Examples from Santos, Campos and Kwanza Basins. Geological Society, London, Special Publications, 363(1), 207-244.

Rowan, M. G., Jackson, M. P. A., \& Trudgill, B. D. (1999). Salt-related fault families and fault welds in the Northern Gulf of Mexico. AAPG Bulletin, 83(9), 1454-1484.

Rowan, M., Peel, F., \& Vendeville, B. (2004). Gravity-driven fold belts on passive margins. In K. R. McClay (ed.), Thrust tectonics and hydrocarbon systems (Vol. 82, pp. 157-182). AAPG Memoir.

Rowan, M. G., \& Ratliff, R. A. (2012). Cross-section restoration of saltrelated deformation: Best practices and potential pitfalls. Journal of Structural Geology, 41, 24-37.

Serié, C., Huuse, M., Schødt, N. H., Brooks, J. M., \& Williams, A. (2017). Subsurface fluid flow in the deep-water Kwanza Basin, offshore Angola. Basin Research, 29(2), 149-179.

Valle, P. J., Gjelberg, J. G., \& Helland-Hansen, W. (2001). Tectonostratigraphic development in the eastern Lower Congo Basin, offshore Angola, West Africa. Marine and Petroleum Geology, 18(8), 909-927. https://doi.org/10.1016/S0264 -8172(01)00036-8

Vendeville, B. C., \& Jackson, M. P. A. (1992a). The fall of diapirs during thin-skinned extension. Marine and Petroleum Geology, 9(4), 354 371. https://doi.org/10.1016/0264-8172(92)90048-J
Vendeville, B. C., \& Jackson, M. P. A. (1992b). The rise of diapirs during thin-skinned extension. Marine and Petroleum Geology, 9(4), 331-354. https://doi.org/10.1016/0264-8172(92)90047-I

Vendeville, B. C., \& Nilsen, K. T. (1995). Episodic growth of salt diapirs driven by horizontal shortening. In Proceedings Gulf Coast Section SEPM Foundation 16th annual research conference, Houston, Texas, pp. 285-295.

Von Nicolai, C. (2011). The interplay of salt movements and regional tectonics at the passive continental margin of the South Atlantic, Kwanza Basin [Unpublished PhD thesis], Universität Potsdam.

Wagner, B. H., \& Jackson, M. P. A. (2011). Viscous flow during salt welding. Tectonophysics, 510(3-4), 309-326. https://doi. org/10.1016/j.tecto.2011.07.012

\section{SUPPORTING INFORMATION}

Additional Supporting Information may be found online in the Supporting Information section.

How to cite this article: Erdi A, Jackson C. A.-L. What controls salt-detached contraction in the translational domain of the outer Kwanza Basin, offshore Angola?. Basin Res. 2021;33:1880-1905. https://doi.org/10.1111/bre.12539 